\title{
ARTICLE \\ Globalized Cross-Border Insolvency Law: The Roles Played by China
}

\author{
Zinian Zhang ${ }^{1}$
}

Accepted: 19 July 2021 / Published online: 30 August 2021

(c) The Author(s) 2021

\begin{abstract}
This study empirically investigates China's participation in the globalized cross-border insolvency collaboration system. It is the first time for the development of China's cross-border insolvency law to be examined against the background of private international law on foreign judgment recognition and enforcement. The findings of this article reveal that foreign bankruptcy representatives face considerable difficulties in satisfying the treaty and reciprocity requirements when seeking judicial assistance from China, and that local protectionism in favour of China's state-owned and state-linked companies undermines foreign bankruptcy representatives' confidence in approaching China's courts for support. Although there are several court recognitions of foreign bankruptcy judgments in China, this article finds that they are only used to acknowledge the legal status of foreign bankruptcy representatives to meet the demands of government authorities; Chinese courts have not taken a substantial step in recognizing a foreign bankruptcy judgment so as to bar individual creditors' action in the interest of a foreign bankruptcy proceeding. On the contrary, for Chinese bankruptcy representatives seeking assistance abroad, they could take advantage of the liberal judicial infrastructure, especially of some advanced jurisdictions, to obtain recognition and relief.
\end{abstract}

Keywords Cross-border · Insolvency $\cdot$ China $\cdot$ Foreign judgment $\cdot$ Recognition · Protectionism

Zinian Zhang

z.zhang2@leeds.ac.uk

1 Lecturer in business law at the School of Law, University of Leeds, Liberty Building,

Leeds LS2 9JT, West Yorkshire, UK 


\section{Introduction}

The international debates ${ }^{1}$ over universalism or modified universalism ${ }^{2}$ in dealing with cross-border insolvency seem to have been largely settled, since the vast majority of advanced jurisdictions have nowadays preferred to closely collaborate with each other so as to promote efficiency and safeguard fairness. ${ }^{3}$ At the time of writing, the UNCITRAL Model Law on Cross-Border Insolvency (the Model Law), ${ }^{4}$ a set of recommended principles advocating modified universalism, has been adopted by 47 countries, notably the USA, Japan, the UK, Australia, Canada, and Singapore. ${ }^{5}$ This is a remarkable achievement in the direction of modified universalism, although many difficult issues remain and some new challenges emerge. ${ }^{6}$

It is noteworthy that although some developed countries, such as Germany, ${ }^{7}$ France $^{8}$ and the Netherlands, ${ }^{9}$ have not officially incorporated the Model Law into domestic legislation, cross-border insolvency can still be adequately dealt with under other domestic laws regarding the conflicts of private international law. Needless to say, given that Germany, France and the Netherlands are EU member states, they are bound by the EU Insolvency Regulation, ${ }^{10}$ arguably the zenith of the practice of modified universalism, ${ }^{11}$ to cooperate at least with other fellow EU member states on transnational insolvencies. ${ }^{12}$

Apart from the aforementioned legal mechanisms in practising modified universalism, many common law jurisdictions have traditionally been resorting to common law to grant assistance to foreign bankruptcy representatives so as to achieve similar goals. A notable example is Hong Kong where the Model Law has not been adopted but local courts frequently rely on common law to assist foreign insolvency

\footnotetext{
1 See the support for universalism or modified universalism at, for example, Westbrook (2018), pp 1475-1476.

2 Many question universalism or modified universalism, but most critics agree that international cooperation, in one way or another, is essential for cross-border insolvency, whatever form of modified universalism or territorialism is preferred. See for example LoPucki (1999), p 742; McCormack (2012), p 347; Walters (2019), p 47.

3 A typical example of international cooperation is the recent Korean bankruptcy case of Daebo International Shipping Co. Ltd. in which the Korean bankruptcy proceeding was opened on 6 March 2015 and was promptly recognised in Japan on 9 March 2015, in the UK on 16 March 2015, in the USA on 19 March 2015 and in Australia on 8 May 2015; this case is cited in Deane and Mason (2016), pp 157-158.

4 United Nations Commission on International Trade Law (UNCITRAL) Model Law on Cross-Border Insolvency (1997), https://uncitral.un.org/en/texts/insolvency/modellaw/cross-border_insolvency. Accessed 20 April 2010.

5 UNCITRAL Model Law on Cross-Border Insolvency (1997), Status, https://uncitral.un.org/en/texts/ insolvency/modellaw/cross-border_insolvency/status. Accessed 20 April 2020.

6 See Walters (2020), p 92; Moss (2019), p 24.

7 See generally Paulus (2019), p 27.

8 See Trautman et al. (1993), p 577; Kirshner (2013), p 31.

9 See Wessels (2008), p 144.

10 Regulation (EU) 2015/848 of the European Parliament and of the Council of 20 May 2015 on insolvency proceedings [2015] OJ L 141/19 (Recast).

11 See generally Fletcher (2014), pp 530-532.

12 See a comprehensive study of the EU Insolvency Regulation (Recast) at McCormack (2016).
} 
proceedings. ${ }^{13}$ In fact, for many common law countries that have adopted the Model Law, domestic courts keep on using common law to fill the gaps left by the Model Law. ${ }^{14}$ Namely, the spirits of modified universalism are fulfilled in these jurisdictions, albeit through a combination of different means. ${ }^{15}$

To a certain extent, it seems safe to say that modified universalism, culminating in the Model Law, has been leading the development of cross-border insolvency law especially since the late twentieth century. ${ }^{16}$

However, it should not be forgotten that this world is unevenly developed. ${ }^{17}$ Many developing countries, especially several major emerging economies, such as Brazil, Russia, India and China, have not adopted the Model Law, and there is no sign that these countries may do so in the near future. ${ }^{18}$ In particular, among all developing countries, the demand for China's participation on cross-border insolvency seems to be most pressing, since China, a country attracting the world's second largest share of inward foreign direct investment consecutively in recent decades and contributing the world's second largest amount of outward foreign direct investment on an annual basis since $2016,{ }^{19}$ appears to be the most integrated with the global economy, as a result of which many business failures inevitably lead to cross-border insolvency coordination requests from and to China.

This article empirically investigates how China deals with cross-border insolvency to understand the way the most globalised developing economy interacts with the outside world in handling cross-border insolvencies, enriching the debate regarding how developing countries embrace global norms. ${ }^{20}$

Although China has not officially adopted the Model Law, China did send, whatever its motivations, ${ }^{21}$ a cooperative signal to the world by adding an ad hoc crossborder collaboration provision, Article 5, which reflects the key principles of modified universalism, into its Enterprise Bankruptcy Law of 2006 (the EBL 2006). ${ }^{22}$ But the irony is that up until now there have been only a handful of cases in which Chinese courts have granted assistance to foreign bankruptcy proceedings. ${ }^{23}$ It is not even an exaggeration to say that there seems to be a deadlock in China's cross-border insolvency law, in spite of repeated insolvency assistance requests from abroad. ${ }^{24}$

So it is legitimate to ask several questions: Why is the Chinese novel cross-border insolvency law rarely used? What factors hinder the Chinese courts from granting recognition and relief to foreign bankruptcy proceedings? And will China eventually

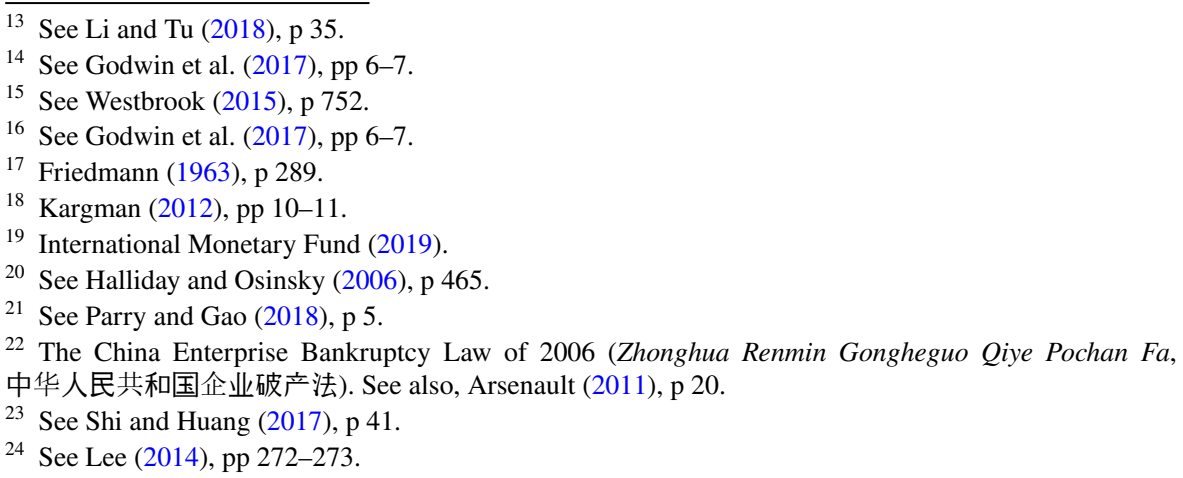


evolve like other civilised jurisdictions to adequately uphold modified universalism so as to effectively contribute to global cooperation in cross-border insolvency?

Through answering these questions, this article attempts to fill three gaps in academic literature. First, unlike other studies ${ }^{25}$ interpreting Article 5 of the EBL 2006 mainly by reference to the Model Law, this article ventures to untangle the enigma of the scarce use of the Chinese new cross-border insolvency law by examining it in the context of how Chinese courts recognise and enforce foreign judgments, since many may have forgotten that cross-border insolvency law is part of private international law, ${ }^{26}$ one pillar of which is the recognition and enforcement of foreign judgments. ${ }^{27}$ The challenges facing the use of Article 5 of the EBL 2006 could be better understood after anatomising the difficulties encountered in seeking the recognition and enforcement of foreign judgments in China. In this article, a foreign bankruptcy judgment means a court order/decision opening a corporate bankruptcy procedure, which means that recognising a foreign bankruptcy judgment largely equates with recognising a foreign bankruptcy proceeding.

Second, this article is perhaps the first empirical study exploring how China's current cross-border insolvency system works in practice by collecting both quantitative and qualitative data; apart from having collected the most inclusive data ${ }^{28}$ on the cases which have recognised and enforced foreign judgments, including recognising foreign bankruptcy judgments/proceedings, ${ }^{29}$ the author also travelled to China twice in the summer and winter of 2019 respectively, visiting eight cities and interviewing sixteen lawyers, twelve judges, two accountants and one senior official, some of them involved in high-profile cross-border insolvencies, such as the transnational bankruptcies of Hanjin Shipping Co., Ltd. and Lehman Brothers International (Europe) Limited. The first-hand data from these frontline practitioners may help to reshape the debate on the development of China's cross-border insolvency law.

Third, in order to paint a full picture of China's cross-border insolvency law in action, this article moves beyond only examining the existing Chinese court cases, in which the courts have recognized foreign bankruptcy judgments/proceedings, and sheds light equally on the cases in which the foreign bankruptcy recognition petition has been silently rejected and thus has not been widely reported and studied by scholars. Without studying the latter, only half of China's cross-border insolvency story can be told, and this article aims to address this gap as well.

To this end, the rest of this article proceeds in three parts. Section 2 examines the legal framework of China's cross-border insolvency system. Section 3 reports the findings generated from the fieldwork in China. Section 4 summarises and makes some policy recommendations.

\footnotetext{
25 See an excellent research paper contributed by Professor Rebecca Parry and her co-author Nan Gao at Parry and Gao (2018).

26 Blom-Cooper (1954), pp 605-608.

27 Kotuby (2013), p 411.

28 Zhang (2013), p 143.

29 UNCITRAL Model Law on recognition and enforcement of insolvency-related judgments with guide to enactment (2019), p 4.
} 


\section{The Legal Framework of China's Cross-Border Insolvency Law Before and after 2006}

China did not have an ad hoc cross-border insolvency law until the year 2006 when the EBL 2006 was promulgated. Prior to the EBL 2006, corporate insolvency was governed by two statutes: the China Enterprise Bankruptcy Law 1986 (For Trial Implementation) (the EBL 1986) for the bankruptcy of state-owned enterprises only, and the China Civil Procedure Law 1991 Chapter 19 providing rules for the bankruptcy of non-state-owned enterprises. Like in some other developing countries, ${ }^{30}$ before 2006, the Chinese lawmakers were not aware of cross-border insolvency, as a result of which there was no provision in these two statutes specifying the ways in which cross-border insolvency should be dealt with. ${ }^{31}$ But the absence of a specific cross-border insolvency law does not mean that there was no rule applicable to cross-border insolvency challenges arising from reality.

\subsection{China's Cross-Border Insolvency Rules Before 2006}

Prior to the EBL 2006, there were generally three sources of legal rules supporting cross-border insolvency cooperation as far as China was concerned. The first is judicial assistance treaties on civil and commercial matters.

At the time of writing, China has entered into such treaties with 33 countries, including France, Italy, Russia, Poland, and Belgium. ${ }^{32}$ Unfortunately, China has yet to conclude such bilateral treaties with its top trading partners, such as the USA and Japan. ${ }^{33}$ According to these treaties, a foreign civil or commercial judgment could be recognised and enforced in China, and vice versa. ${ }^{34}$

\footnotetext{
${ }^{30}$ For example, in Brazil, up until now, its bankruptcy statute does not contain any cross-border collaboration provisions at all. See Colombo et al. (2020).

31 Shi (2002b), pp 115-116; Parry and Gao (2018), p 8.

32 According to the website of the Chinese Justice Ministry at www.chinalaw.gov.cn visited on 13 and 14 May 2020, the following 33 countries have a judicial assistance treaty on civil and commercial matters with China, which could assist the recognition of a foreign bankruptcy proceeding in China: Algeria (signed in 2010), Argentina (2001), Belarus (1993), Bosnia (2013), Brazil (2009), Bulgaria (1993), Cyprus (1995), Cuba (1992), Egypt (1994), Ethiopia (2014), France (1987), Greece (1994), Hungary (1995), Italy (1991), Kazakhstan (1993), Kuwait (2007), Kyrgyzstan (1996), Laos (1999), Lithuania (2000), Mongolia (1989), Morocco (1996), North Korea (2003), Poland (1987), Romania (1991), Russia (1992), Spain (1992), Tajikistan (1999), Tunisia (1999), Turkey (1992), UAE (2004), Ukraine (1992), Uzbekistan (1997), and Vietnam (1998). On the same website, it can be seen that China also has judicial assistance treaties on civil and commercial matters with Singapore, Thailand, Peru and South Korea, but these treaties cannot support the recognition of foreign bankruptcy judgments. In particular, the Singapore, Thailand, and South Korea treaties only support the recognition of arbitral awards, and the Peru treaty explicitly excludes insolvency/bankruptcy issues. There is a judicial assistance arrangement between China and Hong Kong agreed in 2019, which excludes bankruptcy issues. China also has a judicial assistance arrangement with Macau, which could be used to recognise a bankruptcy judgment with regard to each other.

33 Blackwell (2017).

34 See Tsang (2017), p 5.
} 
One may ask whether these judicial assistance treaties exclude bankruptcy judgments, as many international treaties do. ${ }^{35}$ After closer reading, only one treaty between China and Peru explicitly states the exclusion of insolvency matters, ${ }^{36}$ in addition to a judicial arrangement between Mainland China and Hong Kong excluding bankruptcy judgments. ${ }^{37}$ It appears that the vast majority of bilateral treaties entered into by China do not explicitly state whether bankruptcy issues should be excluded or not, ${ }^{38}$ and that it could also be understood that most treaties are intended to cover issues as widely as possible.

More importantly, the current Chinese judicial practice suggests that a foreign bankruptcy judgment is routinely treated as a commercial judgment and is covered by these treaties. ${ }^{39}$ For example, in Re B\&T Ceramic Group S.R.L., the Chinese Foshan Intermediate People's Court, in 2000, recognised an Italian bankruptcy judgment by relying on the Sino-Italian Bilateral Judicial Assistance Treaty over Civil and Commercial Matters, ${ }^{40}$ and later, in 2005, the Chinese Guangzhou Intermediate People's Court followed suit and recognised a French bankruptcy judgment under the Sino-French Bilateral Judicial Assistance Treaty on Civil and Commercial Matters. ${ }^{41}$ Hence, the scope of these treaties is probably broad enough to cover crossborder insolvency cooperation.

The second source of law supporting cross-border insolvency in China is the principles of private international law on recognising and enforcing foreign judgments enshrined in Chapter 29 of the China Civil Procedure Law 1991. ${ }^{42}$ Article 267 of this Law stipulates that a foreign judgment can be recognised and enforced in China either on the condition that there is a judicial assistance treaty between China and the foreign country or on the basis of reciprocity established between them. As noted above, having a judicial assistance treaty with China is a significant advantage; without a treaty, for a foreign bankruptcy representative, relying on

\footnotetext{
35 For example, the 1968 Brussels Convention on Jurisdiction and the Enforcement of Judgments in Civil and Commercial Matters Art. 1 explicitly excludes insolvencies.

${ }^{36}$ Art. 21(3) of the Judicial Assistance Treaty on Civil and Commercial Matters between the People's Republic of China and the Republic of Peru (Zhonghua Renmin Gonghe Guo He Milu Gonghe Guo Guanyu Minshi He Shangshi Sifa Xiezu De Tiaoyue, 中华人民共和国和秘鲁共和国关于民事和商事司 法协助的条约) signed on 19 March 2008 in Beijing, http://www.moj.gov.cn/Department/content/201812/25/358_182485.html. Accessed 25 June 2021.

37 Art. 3 of the Arrangement on Reciprocal Recognition and Enforcement of Judgments in Civil and Commercial Matters by the Courts of the Mainland and of the Hong Kong Special Administrative Region agreed on 18 January 2019, https://www.doj.gov.hk/en/mainland_and_macao/pdf/Doc6_48135 4e.pdf. Accessed 25 June 2021.

38 See Chua (2006), p 560.

39 See Duan (2011), p 20.

40 The Chinese Foshan Intermediate People's Court (2001) Shenqing chenren he zhixing yidali fayuan pochan caijue an (申请承认和执行意大利法院破产裁决案) [Re B\&T Ceramic Group S.R.L.], http:// pkulaw.cn/fulltext_form.aspx?Db=qikan\&Gid=898201b2590ca45a1fbd2454ba16f2e3bdfb\&keyword=\& EncodingName $=\&$ Search_Mode $=\&$ Search_IsTitle=0. Accessed 12 May 2020.

41 Wang and Lian (2008).

42 The China Civil Procedure Law of 1991 (Zhonghua Renmin Gongheguo Minshi Susong Fa, 中华人民 共和国民事诉讼法), http://www.people.com.cn/zixun/flfgk/item/dwjjf/falv/9/9-1-1-01.html. Accessed 5 May 2020.
} 
the principle of reciprocity to persuade Chinese courts is also possible but could be very challenging in practice, because the Chinese courts interpret reciprocity very narrowly.

The third source is some judicial opinions issued by the China Supreme People's Court (the Supreme Court) guiding, or relevant to, cross-border insolvency. In 1988, the Court released Judicial Opinions of Implementing the China General Principles of Civil Law of $1986,{ }^{43}$ Article 184 of which states that the civil capacity of a foreign legal person is subject to the law of the country in which it is incorporated, suggesting that who can represent a foreign company is determined by the law of the foreign country. This implies that a foreign bankruptcy representative could represent the company in China in order to carry out legal activities, such as collecting and disposing of the company's assets or suing and being sued on behalf of the company before a Chinese court. ${ }^{44}$

In fact, this arrangement can be traced back to an earlier judicial notice issued by the Supreme Court in 1987, the Judicial Replies to the Several Questions on the Disputes Involving Parties from Hong Kong and Macau, Article 4(3) of which states that a bankruptcy representative from Hong Kong or Macau could act as the legitimate representative of a company before the Chinse courts to sue or to be sued. ${ }^{45}$ Given that Hong Kong and Macao are treated as foreign jurisdictions even after they were handed back to China in 1997 and in 1999 respectively, ${ }^{46}$ it is reasonable to assume that a bankruptcy representative from a third country could be treated in the same way without any formality.

The automatic recognition of the legal status of a foreign bankruptcy representative seems to be reinforced by a conference memorandum, the Minutes of the Second National Conference on Trials of Cross-Border Commercial and Marine Disputes, released by the Supreme Court in 2005, and its Section 2(15) clarifies that the foreign bankruptcy representative should be notified to represent the foreign company in the Chinese lawsuit if the foreign party enters into a bankruptcy procedure before the lawsuit is concluded. ${ }^{47}$

Before moving on to consider the cross-border rules in the EBL 2006 in the following section, it should be reiterated that the three aforementioned sources of relevant cross-border insolvency rules are still applicable even after 2006, although

\footnotetext{
43 The China Supreme People's Court (1988) Guanyu guanche zhixing zhonghua renmin gongheguo minfa tongze ruogan wenti de yijian (关于贯彻执行中华人民共和国民法通则若干问题的意见) [The judicial opinions on implementing the China General Principles of Civil Law of 1986], http://www.lawlib.com/law/law_view.asp?id=203. Accessed 5 May 2020.

44 McDonald v. Golden Dynasty Enterprises Ltd [2008] 5 HKLRD 569.

45 The China Supreme People's Court (1987) Guanyu shenli she gang'ao jingji jiufeng anjian ruogan wenti de jieda (关于审理涉港澳经济纠纷案件若干问题的解答) [The judicial replies to several issues on the disputes involving parties from Hong Kong and Macau], Beijing, China, 19 October 1987, Fa Jing Fa [1987] 28, http://www.law-lib.com/law/law_view.asp?id=4613. Accessed 5 May 2020.

46 Gong (2011), p 58.

47 The China Supreme People's Court (2005) Dierci quanguo shewai shangshi haishi shenpan gongzuo huiyi jiyao (第二次全国涉外商事海事审判工作会议纪要) [The minutes of the second national conference on trials of cross-border commercial and marine disputes], Nanjing Jiangsu China, 15-16 November 2005, http://www.cmla.org.cn/zl/flfk/haishangfa/2018/0717/2110.html. Accessed 5 May 2020.
} 
some have been amended in recent years. ${ }^{48}$ Many hope that the most recent insolvency legislation, the EBL 2006, may provide more detailed rules alleviating the legal uncertainties and filling many gaps in China's cross-border insolvency law, but the expectation should be kept low. ${ }^{49}$

\subsection{China's Cross-Border Insolvency Law after the EBL 2006}

The EBL 2006 only has one article, Article 5, on cross-border insolvency, which contains two paragraphs. The first is on outbound cross-border insolvency, stating that a Chinese bankruptcy proceeding binds the company's assets worldwide, having a universal effect. The second paragraph concerns inbound insolvency, articulating that a foreign bankruptcy judgment could be recognised and enforced in China if the foreign company has assets located in China, subject to the condition that there is either a treaty or the principle of reciprocity between China and the foreign country, and that the foreign bankruptcy judgment should not breach the general principles of Chinese law, undermine China's sovereignty, securities and public interests, or violate Chinese creditors' legal rights. ${ }^{50}$

Broadly speaking, Article 5 is a step forward: it is the first time for China to clarify its preference in favour of universalism. Whatever the wording, the message is clear: a Chinese bankruptcy judgment has universal effect, and a foreign one has the same effect at least from the perspective of China. It is mutually beneficial. China has moved away from the statutory blankness of the pre-EBL 2006 era.

However, it can also be argued that Article 5 of the EBL 2006 might only be a half-hearted universalism statement for two reasons. First, this Article is literally lopsided: for outbound cross-border insolvencies, the worldwide effect of Chinese bankruptcy proceedings is unconditional, and it seems that the Chinese lawmakers may have forgotten the boundaries of the legislative sovereignty of China as a country; some immediately point out that the declaration of the automatic universal effect of Chinese bankruptcy proceedings is unrealistic, since it depends on cooperation from foreign authorities; ${ }^{51}$ for inbound insolvencies, the tone is harsh, ${ }^{52}$ and, as noted above, condition after condition are laid upon an inbound bankruptcy proceeding recognition request, which leads to many commenting that Article 5 of the EBL 2006 is considerably hostile to foreign bankruptcy proceedings. ${ }^{53}$

Second, Article 5 of the EBL 2006, in particular its Paragraph 2, is perhaps too restrictive and skeletal to be useful. Meeting the complex conditions set out in

\footnotetext{
${ }^{48}$ The China Civil Procedure Law of 1991 was revised on three occasions in 1997, 2012 and 2017 respectively, but the provisions regulating the recognition and enforcement of foreign judgments remain unchanged. The Judicial Replies to Several Questions on the Disputes Involving Parties from Hong Kong and Macau issued by the China Supreme People's Court in 1987 were revoked by the Court in 2013.

49 Shi (2002a).

50 See the EBL 2006 translated into English by China University of Political Science and Law (2008), Enterprise Bankruptcy Law of the People's Republic of China, Int'l Insolvency Rev 17:33-55.

51 See Zheng (2012), p 127.

52 Kargman (2012), p 10.

$53 \mathrm{Li}(2019), \mathrm{p} 1065$.
} 
Article 5 Paragraph 2 can be very challenging, since most of these conditions are vague enough to be insurmountable. For example, a foreign bankruptcy proceeding seeking recognition in China cannot contradict the general principles of Chinese law, but as for what these general principles are, perhaps few can answer. In the meantime, there are too many statutory gaps which remain unfilled by this Article. For example, if a foreign bankruptcy proceeding/judgment is recognised in China, can a general moratorium barring individual action against the company's assets across China be granted simultaneously or subsequently? Can the foreign bankruptcy representative be assisted in moving assets from China back to his/her own country? And can a secondary proceeding be commenced in China for more effective collaboration?

And it may also not bode well if a comparison between Article 5 of the EBL 2006 and Articles 281 and 282 of the China Civil Procedure Law 1991, the provisions on recognising and enforcing foreign judgments, can be made, since arguably the former is largely cut and pasted from the latter. ${ }^{54}$ The only difference would be that the phrase 'foreign judgment' is changed to 'foreign bankruptcy judgment'. This means that Article 5 does not make any breakthrough in advocating international collaboration on cross-border insolvency, since it merely repeats the same principles as those already embedded in the China Civil Procedure Law 1991 which was enacted decades ago. Many kindly praise that Article 5 of the EBL 2006 is a new start, ${ }^{55}$ but this article believes that perhaps nothing new has been enacted. Article 5 is arguably a repeated policy statement only and is too general to offer any practical guidance.

Many expect the China Supreme People's Court to issue detailed judicial opinions to feed certainty on cross-border insolvency, ${ }^{56}$ but most will be disappointed; at the time of writing, three pieces of judicial opinions on bankruptcy trials have been made by the Supreme Court, none of them shedding light on cross-border insolvency. ${ }^{57}$ In 2018, the Supreme Court organized a national bankruptcy conference, which resulted in conference minutes (the 2018 minutes), ${ }^{58}$ Section 9 of which sheds light on cross-border insolvency but only reiterates some general principles which are in line with Article 5 of the EBL 2006. Furthermore, to some extent, Section 9 of the 2018 minutes appears to be half-baked. This Section states that if a foreign bankruptcy judgment is recognised in China under Article 5 of the EBL 2006, the company's assets located in China could be distributed according to the general foreign bankruptcy asset distribution plan after fully paying domestic secured creditors, employees and tax authorities. Actually, in order to do this, this means that a

\footnotetext{
$54 \mathrm{Bu}$ (2009), p 202.

55 Parry and Gao (2018).

56 See generally Ahl (2019), p 268.

57 The China Supreme People's Court issued three pieces of judicial opinions on the implementation of the EBL 2006 in 2011, 2013 and 2019 respectively, but no provision was made for cross-border insolvency.

58 The China Supreme People's Court (2018) Quanguo fayuan pochan shenpan gongzuo huiyi jiyao (全国 法院破产审判工作会议经要) [The minutes of the national bankruptcy conference], Shenzhen Guangdong China, 6 March 2018, http://www.law-lib.com/law/law_view.asp?id=611087. Accessed 10 May 2020.
} 
secondary proceeding must be opened in China, but again the Court remains silent on whether and how a secondary proceeding can be allowed in China.

Hence, generally speaking, there is little specific guidance on cross-border insolvency law in China, even after the enactment of the EBL 2006 Article 5. But the indifference of the Chinese lawmakers concerning cross-border insolvency does not mean that there is no demand in practice, and the following part reports on how cross-border insolvency is dealt with in reality.

\section{Findings on How Cross-Border Insolvency is Dealt with in China}

Since there are only four reported foreign bankruptcy recognition cases in China up until now, anatomising these four cases to understand how cross-border insolvency is handled in China appears to be less persuasive. As noted before, understanding China's cross-border insolvency law will be considerably enhanced if the Chinese ways of recognising and enforcing foreign judgments in general could be studied. ${ }^{59}$

This article has managed to collect 30 foreign judgment recognition cases, listed in Table 1. Although the author could confidently claim that this is the most inclusive list of foreign judgment recognition cases taking place in China between 1994, a year when the first foreign judgment recognition happened in China, and the end of 2018, a time selected to mark the finishing point of the data collection in order to make this project manageable, one caveat should be addressed. These cases are formally counted here, mainly because they were officially accepted by the Chinese courts, as a result of which the applications went through the official court recognition processes. But it is equally worth noting that some, if not most, foreign judgment recognition petitions are silently declined and are even not allowed to enter into an official recognition procedure, so that the case collection in this article might still be just the tip of an iceberg.

Also, as noted in the introduction, this article finds several quietly-declined foreign bankruptcy recognition attempts to reinforce the understanding generated from the study over recognising and enforcing foreign judgments generally in China.

\subsection{The General Patterns and Trends of Foreign Judgment Recognition in China from 1994 to 2018}

Table 1 includes all 30 foreign judgment recognition cases taking place in China from 1994 to 2018. This article can confidently claim that this is the most inclusive list of Chinese foreign judgment recognition cases. Out of the 30 cases, there are four foreign bankruptcy judgment recognition applications, one from Italy, one from France, one from Hong Kong, and one from Germany.

These 30 judgments are from 19 countries/jurisdictions, eight of them from Asia (Hong Kong, Israel, Japan, Singapore, South Korea, Turkey, UAE, and Uzbekistan),

$\overline{59}$ See McCormack and Wan (2019), pp 285-287. 


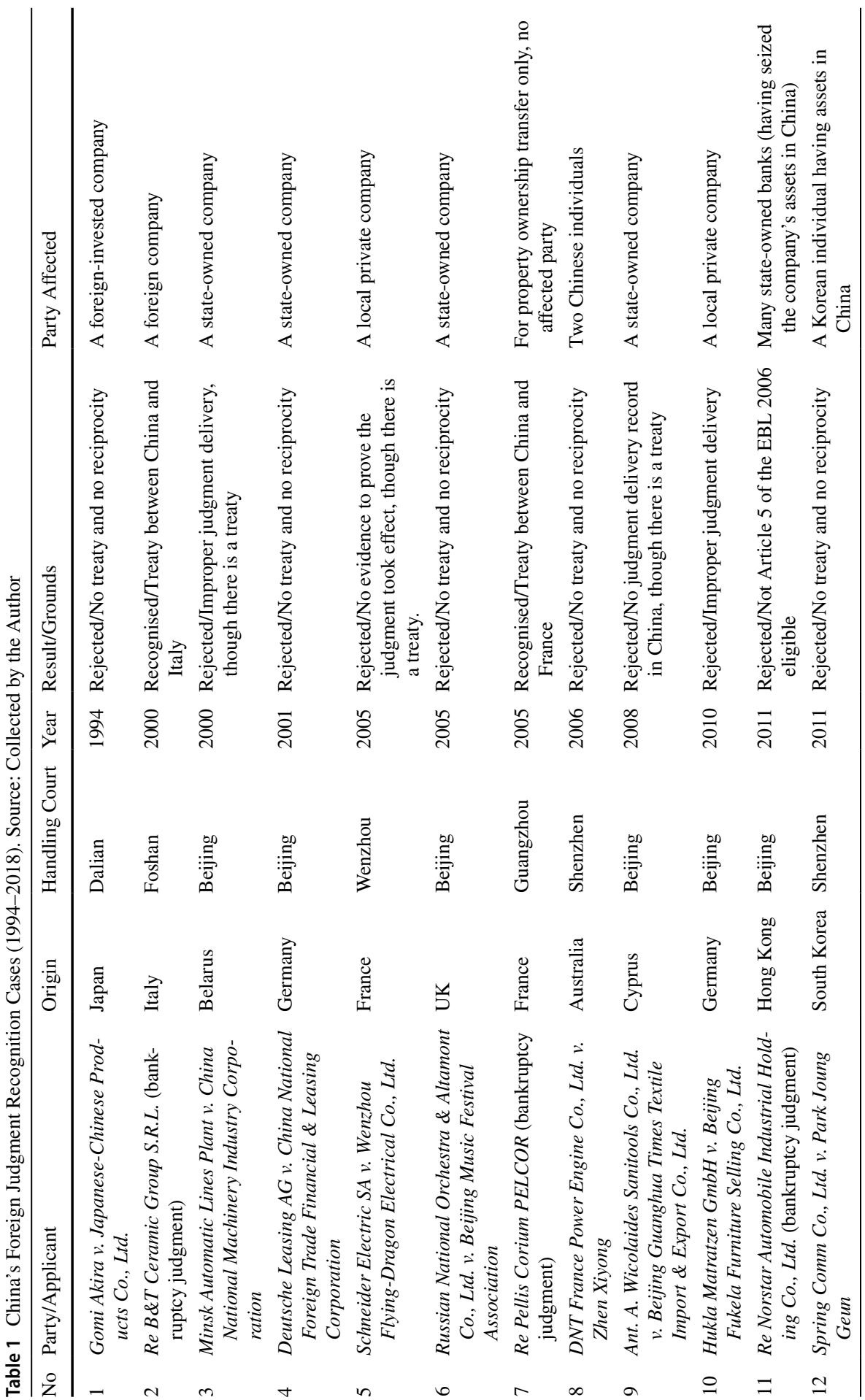




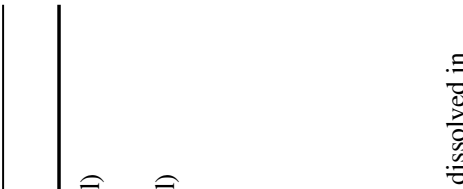

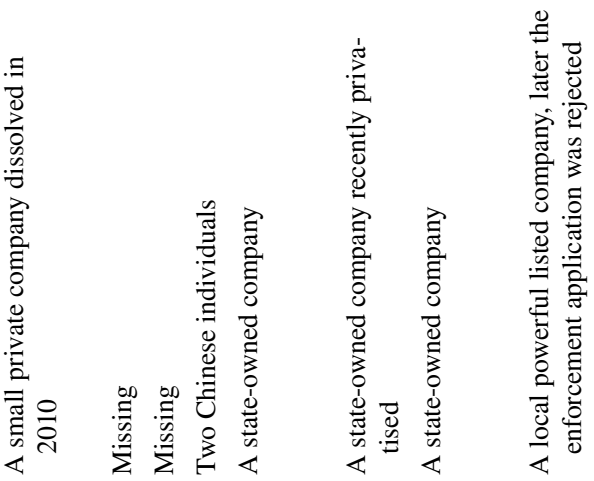



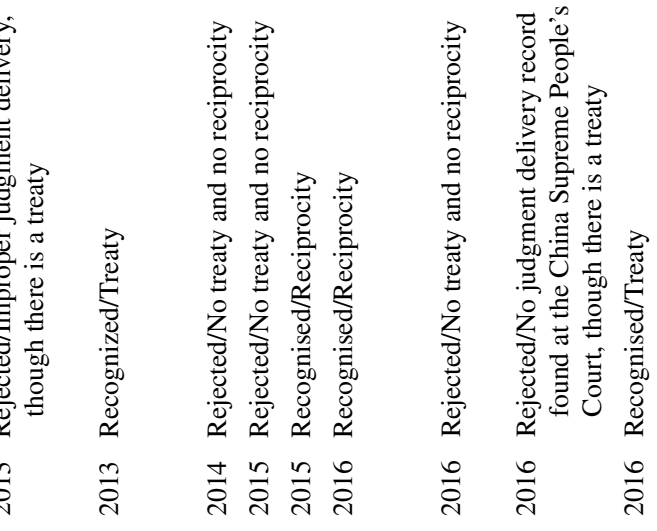

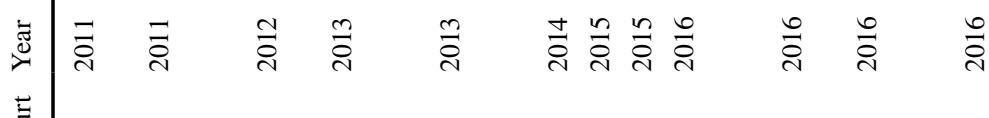

远



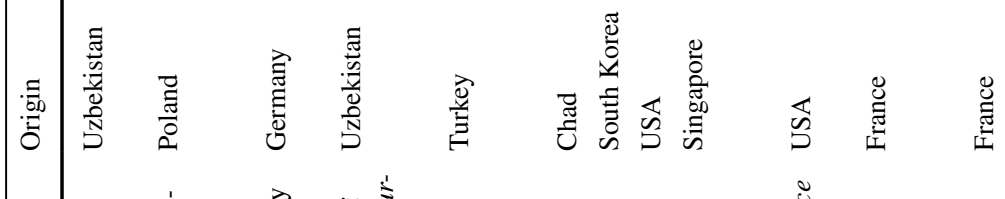

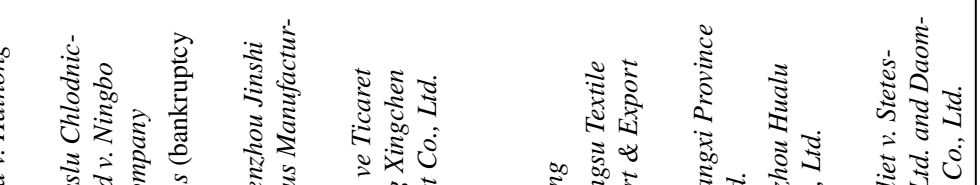

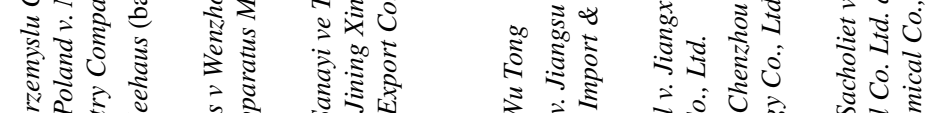

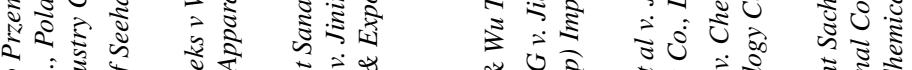

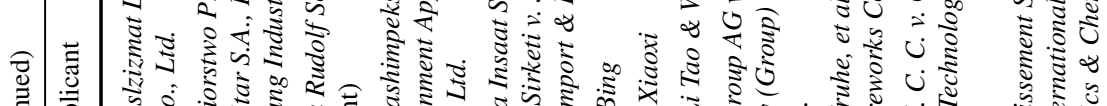

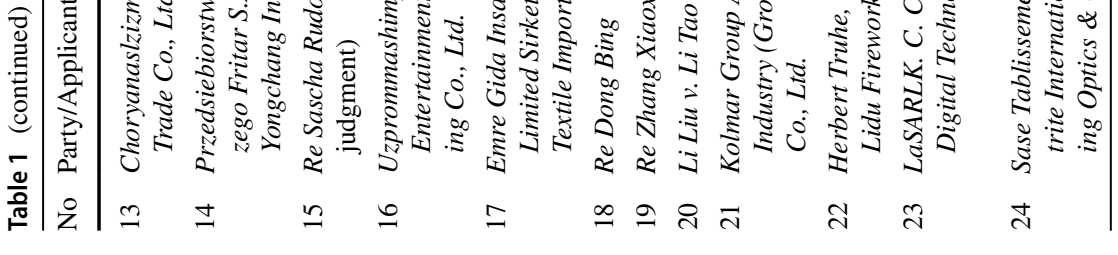




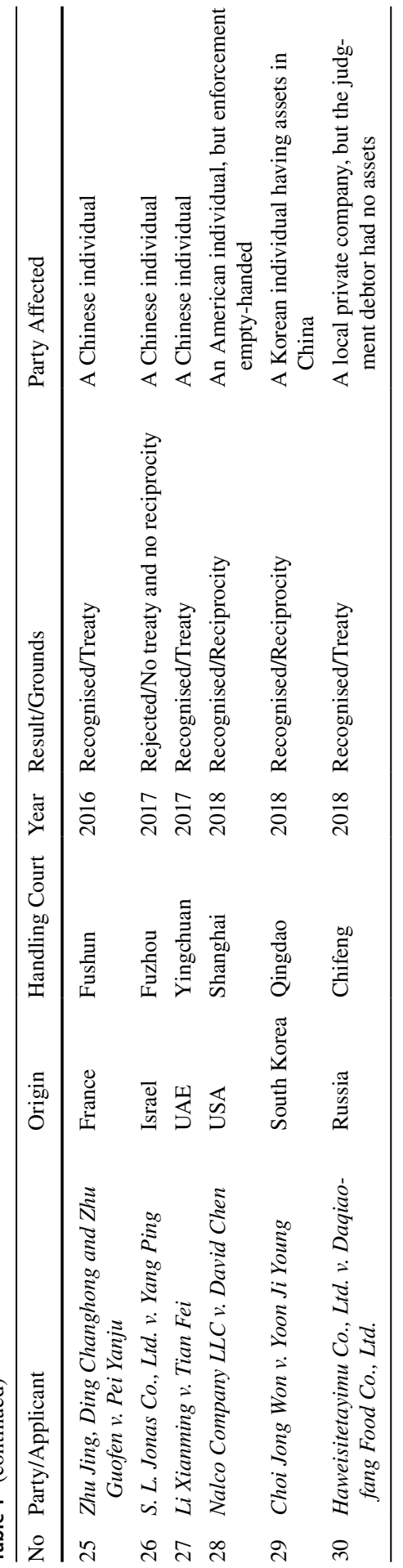




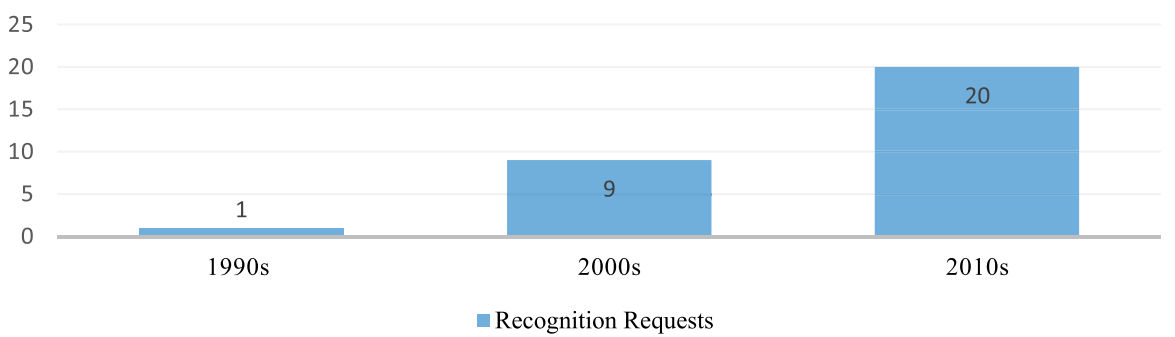

Fig. 1 The Numbers of Foreign Judgments Requesting Recognition in China during the Past Three Decades. Source: Compiled by the Author

another eight from Europe (Belarus, Cyprus, France, Germany, Italy, Poland, Russia, and the UK), one from North America (USA), one from Australasia (Australia), and one from Africa (Chad). Such a wide range of foreign jurisdictions suggests how interconnected China is. Many of the requesting jurisdictions are actually China's major trading partners, like the USA, Japan, Hong Kong, South Korea, France, and Germany. ${ }^{60}$

The top four jurisdictions from which the judgments originated are France (five judgments), Germany (three), South Korea (three) and the USA (three), reflecting their close economic link with China. From a historical perspective, apparently the number of foreign judgment recognition requests increased exponentially in the past three decades. Figure 1 shows that in the 1990s there was only one foreign judgment recognition request in China, but in the 2000s the number jumped to nine; in the 2010s (only counted up to the end of 2018) it soared to twenty. Given that China is becoming more integrated with the global economy, such requests may keep rising in the foreseeable future.

To some extent, these 30 foreign judgment requests are lucky ones, since at least the requested court was kind enough to register the request so as to give the applicant a judicial platform to persuade the judges, but whether a recognition request can be granted by the court is another matter. In fact, as shown in Figure 2, of the 30 recognition applications there were only 13 successful ones, suggesting a $43.33 \%$ success rate; 17 requests $(56.67 \%)$ were ultimately rejected. Although it is premature to jump to the conclusion that a foreign judgment recognition only has a $43.33 \%$ chance of being supported by the Chinese courts, it is safe to say that seeking recognition is considerably difficult in China.

However, a closer inspection can reveal a promising trend suggesting that Chinese courts may be increasingly willing to give the green light for foreign judgments. From 1994 to 2018, not every year saw recognition cases, as shown in Table 1, and, to test the historical trend of the courts' willingness to entertain foreign judgment recognition requests, this article calculates the annual recognition success rate by

\footnotetext{
60 World Trade Organization (2020) Trade country profile, China (recording that China's major trading partners are the USA, the European Union, Hong Kong, Japan and South Korea), https://www.wto.org/ english/res_e/statis_e/daily_update_e/trade_profiles/CN_e.pdf. Accessed 11 May 2020.
} 
counting the number of successful applications out of the total number of recognition efforts in that year. For instance, in 2018, there were three recognition attempts, all of them successful, so that the success rate was $100 \%$; in 2015 , the rate was $50 \%$ since there was one success and one failure; in 2010, the rate was $0 \%$ since there was only one failed request. These rates are summarised and illustrated in Figure 3. Granted, the numbers are too small to depict a full picture; nevertheless, this may still provide a glimpse of hope reflecting the Chinese courts' attitude to foreign judgment recognition requests.

If Figure 3 has some value, it suggests that at least since the year 2015 foreign judgment recognition petitions are increasingly likely to be supported by the Chinese courts. But some uncomfortable issues could be divulged following a more indepth examination, and these unpalatable facts might be exactly what hinders the development of cross-border insolvency law in China and are reported in the next section.

\subsection{Issues Affecting the Recognition of Foreign Judgments in General and of Foreign Bankruptcy Judgments/Proceedings in Particular}

Generally speaking, there are four major hurdles for a foreign judgment recognition request to cross. These four hurdles can also be understood as the factors that substantially affect whether a foreign judgment can be recognised in China. These four hurdles/factors inevitably also apply to foreign bankruptcy judgments seeking judicial assistance from China.

\subsubsection{Having a Judicial Assistance Treaty with China Is Essential for a Foreign Judgment to Seek Recognition in China}

Although there are 13 successful stories out of all 30 recognition cases in China, it is found that eight $(62 \%)$ of them are based on a treaty. For example, as mentioned before, in re B\&T Ceramic Group S.R.L, ${ }^{61}$ this was the first time for an Italian bankruptcy judgment to be recognised in China on the grounds that China has a judicial assistance treaty with Italy signed in $1991 .^{62}$ In 2005, it was also because of the treaty between China and France ${ }^{63}$ that the French bankruptcy judgment of Pellis

\footnotetext{
61 The Chinese Foshan Intermediate People's Court (2000) B\&T Ceramic Group s.r.l. youxian gongsi shenqing chenren he zhixing yidali fayuan pochan panjue an (B\&T Ceramic Group s.r.1. 有限公司申请 承认和执行意大利法院破产判决案) [Recognition of the Italian Bankruptcy Judgment on the Application of B\&T Ceramic Group S.R.L], https://pkulaw.com/pfnl/a25051f3312b07f392faecca5cd80fe8a6d c41d5e9d1ad07bdfb.html. Accessed 13 May 2020.

62 Judicial Assistance Treaty on Civil Matters between the People's Republic of China and Italy (Zhonghua Renmin Gongheguo He Yidali Gongheguo Guanyu Minshi Sifa Xiezu De Tiaoyue, 中华人民共和国 和意大利共和国关于民事司法协助的条约), http://www.moj.gov.cn/Department/content/2018-12/25/ 358_182319.html. Accessed 27 June 2021.

63 Judicial Assistance Treaty on Civil and Commercial Matters between the People's Republic of China and the Republic of France (Zhonghua Renmin Gongheguo He Falanxi Gongheguo Guanyu Minshi Shangshi Sifa Xiezu De Xieding, 中华人民共和国和法兰西共和国关于民事、商事司法协助的协定), http://treaty.mfa.gov.cn/tykfiles/20180718/1531876617542.pdf. Accessed 27 June 2021.
} 
Fig. 2 Results of Foreign Judgment Recognition Petitions in China (1994-2018). Source:

Compiled by the Author

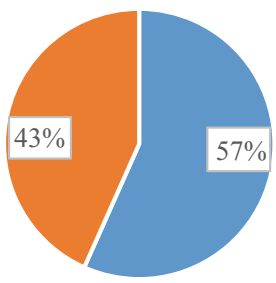

- Rejected (17) = Sanctioned (13)

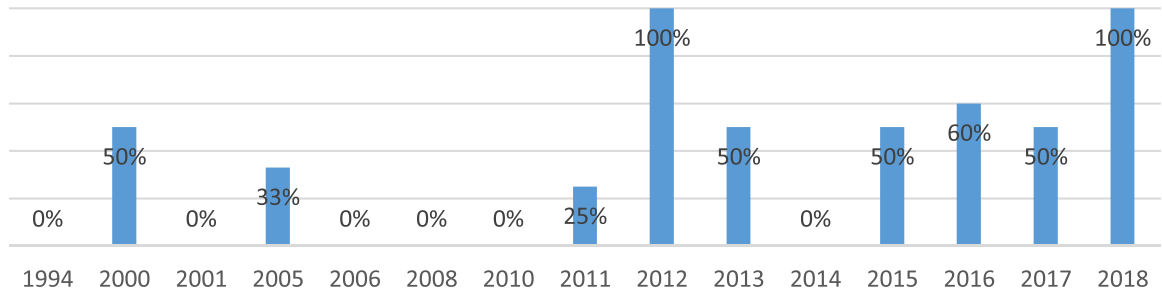

Fig. 3 The Foreign Judgment Recognition Request Success Rates in Some Years between 1994 and 2018 in China. Source: Compiled by the Author

Corium PELCOR was recognised by the Chinese Guangzhou Intermediate People's Court. $^{64}$

But having a judicial assistance treaty is definitely not a guarantee, since it is found that on the rejection list of the 17 foreign judgments, there are six cases ${ }^{65}$ in which there was, and is, a treaty between China and the foreign country but recognition was still declined for various reasons, which will be examined in later parts of this article. Taking into account the eight successful stories above, to some extent this means that there is only a $57 \%$ chance ( 8 out of 14 ) for a foreign judgment from a treaty country to be recognised in China, which is nevertheless higher than the overall success rate of $43 \%$, as noted above.

Admittedly, the treaty requirement facing foreign judgments also troubles foreign bankruptcy decisions. Without having a treaty with China, it is indeed very difficult

\footnotetext{
64 Wang and Lian (2008).

65 These six cases are Minsk Automatic Lines Plant v. China National Machinery Industry Corporation, Schneider Electric SA v. Wenzhou Flying-Dragon Electrical Co. Ltd., Ant. A. Wicolaides Sanitools Co. Ltd. v. Beijing Guanghua Times Textile Import \& Export Co. Ltd., Choryanaslzizmat Limited v. Haihong Trade Co. Ltd., Uzprommashimpeks v. Wenzhou Jinshi Entertainment Apparatus Manufacturing Co. Ltd., and LaSARLK. C. C. v. Chenzhou Hualu Digital Technology Co., Ltd.
} 
to obtain recognition. Even worse, in this situation many Chinese courts may refuse to register recognition applications in the first place. For example, in Hua'an Fund Limited v. Lehman Brothers International (Europe) Limited (the Lehman case) adjudicated in Shanghai, given that the defendant Lehman Brothers International (Europe) Limited had been placed in administration in an English insolvency procedure, on 23 September 2008 in London, ${ }^{66}$ one day before it was sued in Shanghai, the English administrator desperately wanted to have the English bankruptcy proceeding recognised in the Shanghai Municipal High People's Court; ${ }^{67}$ one lawyer representing Lehman Brothers International (Europe) Limited, when interviewed, stated that the English side had submitted a written recognition application to the Court, highlighting that the application was in writing, but the Court simply chose to ignore this application. ${ }^{68}$

This powerful and well-connected Shanghai lawyer also disclosed that the legal team on behalf of Lehman Brothers International (Europe) Limited had even asked the China Supreme People's Court to intervene, and that the national judges in charge of bankruptcy trials had suggested that the Shanghai Municipal High People's Court should consider recognising the English bankruptcy judgment/proceeding in the knowledge that such recognition would boost China's global image as an open and cooperative jurisdiction. ${ }^{69}$ But all efforts did not yield positive results.

However, when a sitting judge in the Lehman case was interviewed in 2019, he denied that there was a written recognition request, but admitted that he was aware that the defendant was involved in an English bankruptcy procedure, insisting that even if there had been a recognition application it was bound to fail since there was no judicial assistance treaty between China and the UK. ${ }^{70}$ Whatever this judge's admission or denial, the key consensual point here is that because the UK did not have a judicial treaty with China, the recognition application, real or potential, was not even worth considering.

The absence of a treaty with China is also one of the key reasons for the bankruptcy proceeding of Hanjin Shipping Co., Ltd., opened in South Korea in 2016, to miss recognition in China. ${ }^{71}$ In the absence of Hanjin's recognition in China, there was a frantic race to seize the company's vessels in Chinese waters shortly after its bankruptcy announcement in 2016. ${ }^{72}$ Puzzled as to why Hanjin did not petition for bankruptcy recognition, ${ }^{73}$ in 2019 the author begged for an answer from a Beijingbased lawyer representing Hanjin in China, who gave a straightforward reply: Hanjin and its legal team were not sufficiently confident to request for recognition since there was no judicial assistance treaty between China and South Korea. ${ }^{74}$

\footnotetext{
${ }^{66}$ Lehman Brothers Europe Limited, Notice of administrator's appointment, 23 September 2008 in the High Court of Justice, Chancery Division, Companies Court, England.

67 See an excellent article examining this case at Zhang (2011).

68 Interview Shanghai-001 (Shanghai China, Tuesday 13 August 2019).

69 Ibid.

70 Interview Shanghai-002 (Shanghai China, 12 August 2019).

71 See Zhou (2016).

72 Lee and Jin (2016).

73 Shi and Huang (2017), p 41.

74 Interview Shanghai-003 (Wuhan Hubei China, 9 August 2019).
} 
For a foreign bankruptcy representative, whether the country has a treaty with China is categorically beyond his/her control. At present, only 33 countries have treaties with China which could support the recognition of foreign bankruptcy judgments, and after examining the times when these treaties were signed, it can be concluded that the likelihood of China entering into new treaties looks slim.

Among the 33 treaties, it is found that there are three treaties signed in the $1980 \mathrm{~s},{ }^{75} 21$ in the $1990 \mathrm{~s},{ }^{76}$ six in the $2000 \mathrm{~s}^{77}$ and only three in the $2010 \mathrm{~s}$, ${ }^{78}$ which tends to suggest that China has apparently lost its enthusiasm when it comes to entering into new treaties after the 2010s. By contrast, China appears to be more interested in signing treaties on criminal law assistance, since it now has such treaties with at least 55 countries, notably the USA, the UK, Canada, Australia, Japan, and South Korea. ${ }^{79}$ Unsurprisingly, China feels that it is more urgent to bring criminals, many of whom are on the wrong side of the ruling class' infighting, back to China to be punished. ${ }^{80}$

Hence, expecting more treaties to promote foreign bankruptcy recognition in China seems to be unrealistic. Without a treaty, under Article 5 of the EBL 2006, a foreign bankruptcy judgment can still be recognised if judicial reciprocity exits between China and the requesting country.

\subsubsection{Reciprocity Can Also Facilitate the Recognition of Foreign Judgments, Including Foreign Bankruptcy Judgments, in China}

As shown in Table 1, out of all 13 successful recognition cases, there are five approvals (38\%) sanctioned on the basis of reciprocity, one of which is the recognition of a German bankruptcy judgment in 2012. ${ }^{81}$

As has been examined by many scholars in China ${ }^{82}$ and outside, ${ }^{83}$ it seems that reciprocity is still narrowly interpreted and stringently applied. In all these five cases, the acknowledgment of reciprocity was based on the fact that there had already been a Chinese judgment which had previously been recognised in the requesting country. In Re Sascha Rudolf Seehaus, for instance, the Chinese Wuhan Intermediate

\footnotetext{
75 The three treaties are those with France in 1987, Mongolia in 1989, and Poland in 1987 respectively.

76 The 21 treaties are those with Belarus (1993), Bulgaria (1993), Cyprus (1995), Cuba (1992), Egypt (1994), Greece (1994), Hungary (1995), Italy (1991), Kazakhstan (1993), Kyrgyzstan (1996), Laos (1999), Morocco (1996), Romania (1991), Russia (1992), Spain (1992), Tajikistan (1999), Tunisia (1999), Turkey (1992), Ukraine (1992), Uzbekistan (1997), and Vietnam (1998).

77 The six treaties are those with Argentina (2001), Brazil (2009), Lithuania (2000), North Korea (2003), Kuwait (2007) and the UAE (2004).

${ }_{78}$ The three treaties are those with Algeria in 2010, Bosnia in 2013 and Ethiopia in 2014.

${ }^{79}$ On the website of the Ministry of Justice of China, www.chinalaw.org.cn, visited on 15 May 2020, there are at least 55 treaties on criminal law assistance that have been entered into by China.

${ }^{80}$ See Levin (2016).

${ }^{81}$ These four cases are Re Sascha Rudolf Seehaus, Li Liu v. Li Tao \& Wu Tong, Kolmar Group AG v. Jiangsu Textile Industry (Group) Import \& Export Co. Ltd. and Choi Jong Won v. Yoon Ji Young.

${ }^{82}$ For example Cheng (2018), p 83.

${ }^{83}$ Cohen (2014), p 566.
} 
People's Court decided to favour Mr Sascha Rudolf Seehaus, the German liquidator of SP Management $\mathrm{GmbH}$, mainly because a commercial judgment delivered by the Chinese Wuxi High-Tech District People's Court had been recognised by a German Berlin court some years previously, namely reciprocity between China and Germany had been established because Germany had taken the first step. ${ }^{84}$ In the other four cases, the Chinese courts applied reciprocity after hearing evidence that Chinese judgments had previously been recognised in Singapore, South Korea and the USA. ${ }^{85}$

But using reciprocity to obtain recognition in China still has to encounter a number of difficulties. First, although there are many ways of practising reciprocity or comity in the international judicial community, ${ }^{86}$ the Chinese way of interpreting the existence of reciprocity might be the most restrictive: before recognising a foreign judgment, reciprocity is assumed not to exist unless and until there is a Chinese judgment that has already been recognised in that foreign country in the first place. ${ }^{87}$ Before 2006, no foreign judgments were recognised in China under the principle of reciprocity (see table 1 above).

It is worth noting that in 2017 the China Supreme People' Court hosted a judicial cooperation conference, with its Asian neighbours as participants, in the Chinese city of Nanning, and the conference was concluded with a so-called 'Nanning Declaration', which announces that reciprocity could be presumed to exist if the requesting country has not declined to recognise court judgments from the requested country in the past. ${ }^{88}$ If reciprocity can be presumed in this way, most countries in the world can rely on this to seek judgment recognition in China. But the problem is that such a good intention has not been translated into action, and up until now there have been no recognitions delivered on presumed reciprocity in China. ${ }^{89}$ Therefore, the Chinese version of reciprocity remains unchanged even after the 2017 Nanning Declaration: 'You must recognise a Chinese judgment before I reciprocate, and I will never do you a favour as the first step to build friendship'.

Following the Nanning Declaration, the Supreme Court immediately announced that a comprehensive judicial notice providing details on the application of presumed reciprocity would be published, ${ }^{90}$ but three years later, and to date, such an ad hoc notice has not yet been released.

In fact, there may be some bad news instead. In December 2019, the China Supreme People's Court issued a judicial notice, the Instruction of Judicial Services

\footnotetext{
84 The Chinese Wuhan Intermediate People’s Court (2012) Minshi caiding shu (民事裁定书) [Civil court order], 2012 E Wuhan Zhong Min Shang Wai Chu Zi Di 00016 Hao.

85 Huang (2019).

86 See generally Coyle (2014).

87 See Simowitz (2019), p 1036.

88 The China Supreme People's Court (2017) The Nanning declaration at the $2^{\text {nd }}$ China-ASEAN justice forum, Nanning, Guangxi, China, 9 July 2017, http://cicc.court.gov.cn/html/1/219/208/209/800.html. Accessed 5 May 2020.

89 See generally Brand (2018), p 47.

90 Luo (2017), p 4.
} 
in Support of the Belt \& Road Initiative, Section 31 of which repeats some judicial rhetoric on improving cross-border insolvency cooperation, but its Section 24 strangely reiterates that presumed reciprocity should be used to promote the recognition of judgments made by China's newly-established international commercial courts abroad. ${ }^{91}$ This implies that China still expects other countries to practise reciprocity, presumed or not, in recognising Chinese judgments first.

Second, in order to prove the existence of reciprocity, the applicant must provide a foreign court judgment/order previously recognising a Chinese judgment, which is not an easy task in practice. At present, the major sources for such information are academic studies ${ }^{92}$ and some news reports. ${ }^{93}$ Two senior judges from the China Supreme People's Court have recently indicated that the Court is considering collecting the recognition of Chinese judgments overseas so as to assist judges in acknowledging and applying established reciprocity, ${ }^{94}$ but this intention has not yet materialised. Without an official list of such cases, inevitably the goodwill of a foreign court may sometimes remain unknown in China, as a result of which reciprocating becomes unlikely.

A typical example is the 2011 recognition case of Spring Comm Co., Ltd. v. Park Joung Geun (the Spring Comm case), included in Table 1. In this case, given that South Korea does not have a judicial assistance treaty with China, the only justification for seeking recognition was to rely on reciprocity under Chinese law; unfortunately, the South Korean applicant, its Chinese lawyer and even the Chinese Shenzhen Intermediate People's Court were unaware that as early as in 1999 there had been a Chinese commercial judgment rendered by the Chinese Weifang Intermediate People's Court which had been recognised by a Seoul Court, South Korea, which meant that, by Chinese standards, reciprocity had been in existence for over a decade between Korea and China. ${ }^{95}$

Because of information asymmetry, the recognition effort made by Spring Comm could not benefit from the established reciprocity, and it should not come as a surprise that the Chinese court straightforwardly rejected the recognition application. ${ }^{96}$ More worryingly, in 2019, when the author met the applicant's Shenzhen lawyer, she was still unaware that there was a Korean case in which a Chinese judgment had been recognised in $1999 .{ }^{97}$ This Shenzhen lawyer should not be blamed, however, since even the author as a researcher has struggled with collecting cases, and surely some cases have been missed in this article.

\footnotetext{
91 The China Supreme People's Court (2019) Guanyu renmin fayuan jingyibu wei yidai yilu jiangshe tigong sifa fuwu he baozhang de yijian (关于人民法院进一步为一带一路建设提供司法服务和保障 的意见) [The instruction of judicial services in support of the Belt \& Road Initiative], Beijing China, 9 December 2019, http://gongbao.court.gov.cn/Details/b10a1d30141bc4a4c7886b00d759c3.html. Accessed 17 May 2020.

92 Chen and Xiao (2018), p 254.

$93 \mathrm{He}(2014), \mathrm{p} 4$.

94 Zhang and Yang (2019), p 24.

95 See Choi Jongwon v. Yoon Ji Young (Qingdao Intermediate People's Court, Shandong, China, Court Civil Order, 2008 Lu 02 Xie Wai Ren 6 Hao).

96 Chen and Xiao (2018), p 262.

97 Interview Shenzhen-001 (Shenzhen Guangdong China, 17 December 2019).
} 
The difficulty in accessing reciprocity-generating foreign judgments might also be one of the reasons as to why the high-profile South Korean bankruptcy procedure of Hanjin Shipping Co., Ltd. did not seek recognition in China, and in principle the South Korean bankruptcy representative could have relied on the established reciprocity, as noted before, to petition for recognition. But the Hanjin Chinese legal team did not do this, or even did not attempt to do so, probably because they also did not know of the aforementioned case.

In 2019, the author interviewed a third lawyer who once represented a Korean bankruptcy representative sued in China, and this lawyer was also unaware of the reciprocity between China and South Korea and she stated that her lawyer colleagues in South Korea once tried to search for such a case but failed to find one. ${ }^{98}$

Many call upon the China Supreme People's Court to establish a database collecting Chinese judgments recognised abroad to ease information asymmetry; ${ }^{99}$ it remains to be seen whether the Court will actively respond to such calls.

Knowing whether there is a Chinese judgment recognised overseas is essential to convince the court that reciprocity has been established, but presenting legally accepted evidence is another matter. Some courts rigidly follow the China Supreme People's Court rules on evidence by requiring that the foreign Chinese judgment recognition order should be notarised by a foreign authority and verified by the Chinese embassy in the country in question, which can be very time-consuming. ${ }^{100}$ However, some courts are very supportive and amenable. For example, one lawyer informed the author that when he applied for the recognition of the first American judgment before the Chinese Wuhan Intermediate People's Court, he did not submit any written evidence proving that a Chinese judgment had been previously recognised in the USA, and that instead he simply stated the fact quoted from newspaper reports; the Wuhan Court accepted this. ${ }^{101}$ Nevertheless, proving the existence of reciprocity remains a challenge.

Third, in recent years, a more restrictive argument regarding the establishment of reciprocity has emerged in China, and although it has not yet been practised by the courts, it may cast a shadow over its future application. The supporters are of the view that if a Chinese judgment is recognised in a jurisdiction having a federal system, especially the USA, reciprocity is deemed to have been established between China and the individual state from which the Chinese judgment was recognised rather than with the foreign national jurisdiction as a whole, since each state within a federal system has many laws that are substantially different from each other. ${ }^{102}$

The widely cited example is that a Chinese judgment was recognised by the US District Court for the Central District of California in $2009,{ }^{103}$ as a result of which

\footnotetext{
98 Interview Qingdao-003 (Qingdao Shandong China, 1 August 2019).

99 Huang (2019).

100 Interview Qingdao-001 (Qingdao Shandong China, 1 August 2019), and Interview Qingdao-002 (Qingdao Shandong China, 2 August 2019).

101 Interview Wuhan-001 (Wuhan Hubei China, 8 August 2019).

102 For example Wang (2019), p 36.

103 Hubei Gezhouba Sanlian Industrial Co., Ltd. v. Robinson Helicopter Company, INC. 2009 WL 2190187 (United States District Court, C.D. California).
} 
reciprocity has only been established between China and the state of California; this coincides with the first American judgment of Liu Li v. Tao Li and Tong Wu rendered by the Los Angeles Superior Court, a state court in California, USA, recognised by a Chinese court in $2017 ; ;^{104}$ the reason is simple: reciprocity exists between China and California.

According to this standard, another American judgment, Herbert Truthe et al v. Jiangxi Province Lidu Fireworks Co., Ltd. (the Lidu case), rendered by the Philadelphia County Court of Common Pleas, the First Judicial District of Pennsylvania, USA, in 2014, ${ }^{105}$ should not have been recognised in China in 2017 because of the absence of reciprocity between China and the state of Pennsylvania. ${ }^{106}$ Interestingly, the recognition petition in the Lidu case was declined by a Chinese court in 2017 on the basis that there was no reciprocity between China and the USA rather than no reciprocity between China and the state of Pennsylvania. ${ }^{107}$

Opponents contend that if reciprocity is interpreted in such a restrictive way, then reciprocity itself will risk becoming totally useless, ${ }^{108}$ and one may be more vocal and assert that there are always endless excuses for the Chinese courts to decline foreign judgment recognition requests. ${ }^{109}$ It is fair to say that although China has many forward-looking and liberal scholars and judges, there are also many hardliners, academics and practitioners, who are considerably hostile to foreigners. ${ }^{110}$

For a foreign bankruptcy representative, understanding how reciprocity is interpreted and practised is vital before seeking judicial assistance from China. Arguably, the requirements of either a treaty or established reciprocity, as examined above, can be viewed as the hard conditions/hurdles that must be met/crossed before a foreign judgment can be recognised in China. By contrast, the following soft conditions might pose higher barriers, making foreign judgment recognition more difficult and equally obstructing foreign bankruptcy judgments seeking recognition in China.

\subsubsection{The Third Hurdle is That Foreign (Bankruptcy) Judgment Recognition Cannot Offend Powerful Local Interests}

This is a soft condition not laid down in the law but practised in reality. Without understanding this condition, many might be bewildered by the fact that the existence of a treaty or reciprocity might be considerably persuasive for a foreign judgment to be recognised in China, but many recognition requests, although they have met such conditions, are still rejected.

For instance, in LaSARLK. C. C. v. Chenzhou Hualu Digital Technology Co., Ltd., although there is a judicial assistance treaty between China and France, recognition of the French judgment was still declined by the Chinese Chenzhou Intermediate

\footnotetext{
104 See Gong (2018).

105 Herbert Truhe and Others v. Janxi [sic] Province Lidu Fireworks Co., Ltd. and Others 2012 WL 2795983 (Pa.Com.Pl.) (Trial Pleading), Court of Common Pleas of Pennsylvania, Philadelphia County.

${ }^{106}$ See generally Coco (2019).

107 Wang (2019), p 35.

${ }^{108} \mathrm{Li}$ and Zhao (2018), p 29.

109 Xie (2010), p 159.

${ }^{110}$ See Liu (2018), p 207.
} 
People's Court in 2016. And, in the Lidu case, although reciprocity between China and the USA had been recently acknowledged and applied by a fellow court, the Chinese Nanchang Intermediate People's Court rejected the American judgment recognition application by stating, shockingly, that there was no reciprocity between China and the USA at all, in spite of the fact that the applicant had provided evidence proving the contrary. ${ }^{111}$

What really matters in this situation is likely to be the status of the party that will be disadvantaged by the recognition of the foreign judgment. To examine how this status may shape the recognition result, this article divides the 27 recognition cases into five groups according to the different status of the party affected by the foreign judgment's recognition; the remaining three cases are not included because the financially affected party is unknown in the first two cases, Re Dong Bing and Re Zhang Xiaoxi, and there is no financially-affected party in Re Pellis Corium PEL$C O R$ in which the French bankruptcy representative sought judicial recognition only for the purpose of completing the official alienation registration of the company's real property in China.

The first of the five groups comprises Chinese state-owned companies that are financially affected parties in a foreign judgment recognition case. As shown in Table 2, this group has seven recognition cases, but unfortunately six of which were rejected and only one was successful. This means that if a foreign judgment recognition application is against a state-owned company in China, there is only a one in seven $(14 \%)$ chance of obtaining recognition. Even $14 \%$ is probably an exaggeration, since in the only successful case, Kolmar Group AG v. Jiangsu Textile Industry (Group) Import \& Export Co., Ltd. (the Kolmar case), the recognition decision was more or less a Chinese diplomatic gift to Singapore, since during that time the China Supreme People's Court was preparing for a significant international conference, the $2^{\text {nd }}$ China-ASEAN Justice Forum, in which China might have needed a case to show its leadership and its judicial credibility to its ASEAN partners, one significant member of them being Singapore. ${ }^{112}$

The challenge of not offending Chinese state-owned companies facing foreign judgment recognitions in general is also what a foreign bankruptcy judgment recognition must face. In fact, confronting Chinese state-owned companies seems to be one key reason why many foreign bankruptcy representatives view the Chinese courts as being hostile. The following cases can support this assertion.

First, in a widely-quoted Chinese cross-border insolvency case, Liwan District Construction Company v. Euro-American China Property Limited (the Liwan case), which took place in 1990, the Hong Kong liquidator was not even allowed to represent the company when attending the hearing at a Chinese court, where the Hong Kong company, Euro-American China Property Limited, in liquidation was being sued; the Guangzhou Court behaved paradoxically, since, on the one hand, it did not recognise the legitimacy of the Hong Kong company's chairman representing the company in the Chinese lawsuit by citing that the company had entered into the bankruptcy liquidation procedure in Hong Kong, but, on the other hand, it also

${ }^{111} \mathrm{He}$ (2018), p 1144.

112 Jiang (2017). 
Table 2 The Fate of Foreign Judgment Recognition against State-Owned Companies in China. Source: Compiled by the Author

\begin{tabular}{|c|c|c|c|}
\hline Parties & Year & Defendant & Result \\
\hline $\begin{array}{l}\text { Deutsche Leasing AGv. China National } \\
\text { Foreign Trade Financial \& Leasing } \\
\text { Corporation }\end{array}$ & 2001 & $\begin{array}{l}\text { A Chinese central government-owned } \\
\text { company }\end{array}$ & Rejected \\
\hline $\begin{array}{l}\text { Minsk Automatic Lines Plant v. China } \\
\text { National Machinery Industry Corpora- } \\
\text { tion }\end{array}$ & 2000 & $\begin{array}{l}\text { A Chinese central government-owned } \\
\text { company }\end{array}$ & Rejected \\
\hline $\begin{array}{l}\text { Russian National Orchestra \& Altamont } \\
\text { Co. Ltd. v. Beijing Music Festival } \\
\text { Association }\end{array}$ & 2005 & $\begin{array}{l}\text { A Chinese local government-owned } \\
\text { agency/company }\end{array}$ & Rejected \\
\hline $\begin{array}{l}\text { Ant. A. Wicolaides Sanitools Co. Ltd. v. } \\
\text { Beijing Guanghua Times Textile Import } \\
\quad \text { \& Export Co. Ltd }\end{array}$ & 2008 & $\begin{array}{l}\text { A Chinese local government-owned } \\
\text { company }\end{array}$ & Rejected \\
\hline $\begin{array}{l}\text { Re Norstar Automobile Industrial Hold- } \\
\quad \text { ing Co., Ltd. }\end{array}$ & 2011 & $\begin{array}{l}\text { Many state-owned banks (having } \\
\text { seized the company's assets in } \\
\text { China) }\end{array}$ & Rejected \\
\hline $\begin{array}{l}\text { LaSARLK. C. C. v. Chenzhou Hualu } \\
\text { Digital Technology Co., Ltd }\end{array}$ & 2016 & $\begin{array}{l}\text { A Chinese central government-owned } \\
\text { company }\end{array}$ & Rejected \\
\hline $\begin{array}{l}\text { Kolmar Group AG v Jiangsu Textile } \\
\text { Industry (Group) Import \& Export Co. } \\
\text { Ltd }\end{array}$ & 2016 & $\begin{array}{l}\text { A Chinese local government-owned } \\
\text { company }\end{array}$ & $\begin{array}{l}\text { Recog- } \\
\text { nised }\end{array}$ \\
\hline
\end{tabular}

denied the legitimacy of the Hong Kong liquidator representing the company on the grounds that the Hong Kong liquidator lacked the authority to act on behalf of the company outside Hong Kong. ${ }^{113}$ This essentially meant that no one could represent the Hong Kong company in the Chinese lawsuit, if the Guangzhou Court was correct. This is apparently against common sense.

The Liwan case is wrong in at least two ways. First, the Guangzhou Court's decision blatantly violated the China Supreme People's Court policy that unequivocally allows Hong Kong bankruptcy representatives to act on behalf of Hong Kong companies in lawsuits in China. ${ }^{114}$ Second, as observed by Professors Zhang Xianchu and Charles Booth, 'liquidators from Hong Kong in many unreported cases have not had difficulty in having the appointment and status recognised in the courts of China, or in commencing and continuing proceedings at various levels of the courts'; ${ }^{115}$ but why did the Guangzhou Court selectively treat the Hong Kong liquidator so harshly in the Liwan case? Puzzled? The answer is also apparent and simple: in the Liwan case, the plaintiff, Liwan District Construction Company, was a local government-owned company, ${ }^{116}$ which is why the Guangzhou Court treated

\footnotetext{
113 Booth and Lewis (1990), p 28.

114 The China Supreme People's Court (1987) Guanyu shenli she gangao jingji jiufeng anjian ruogan wenti de jieda (关于审理涉港澳经济纠纷案件若干问题的解答) [The judicial replies to several issues on disputes involving parties from Hong Kong and Macau], Beijing China, 19 October 1987, Fa Jing Fa [1987] 28, http://www.law-lib.com/law/law_view.asp?id=4613. Accessed 5 May 2020.

115 Zhang and Booth (2002), p 35.

116 Construction Economy (1995).
} 
Liwan District Construction Company so favourably at the expense of the Hong Kong liquidator. When a local state-owned company needs protection, both the law and common sense can be flouted, at least in the Liwan case.

In practising local protectionism in the interest of state-owned companies, Chinese courts behave in a very consistent way. Second, shortly after the Liwan case, in 1992, when an international bank, the Bank of Credit and Commerce International (BCCI), collapsed, its Chinese branch's assets were immediately seized by local creditors through the Chinese Shenzhen Intermediate People's Court; it surprised no one that the Court had no appetite to recognise any foreign bankruptcy proceedings involving BCCI, ${ }^{117}$ because of the same consideration: almost all BCCI Chinese creditors were domestic state-owned banks. ${ }^{118}$ It was a case of state-owned companies first.

Third, the same local protectionism was repeated when the Lehman case was handled in Shanghai in 2008; the Shanghai Court was emboldened to ignore the English party's bankruptcy judgment recognition request, but the real reason that the court probably did not want to disclose was that the Chinese party, Hua' an Fund Limited, is a powerful Shanghai government-owned company. ${ }^{119}$

Fourth, as recently as in 2016, again when Hanjin Shipping Co., Ltd. was placed into a bankruptcy rehabilitation procedure in South Korea, its bankruptcy proceeding was recognised in many advanced jurisdictions, including the $\mathrm{UK}^{120}$ and USA, ${ }^{121}$ but it was not recognised in China. Given that the South Korean government promised to support Hanjin in seeking bankruptcy recognition overseas, presumably there might have been a failed diplomatic effort on the part of the Korean side in China. ${ }^{122}$ With the South Korean Hanjin bankruptcy not being recognised in China, who could benefit from this? Two sources can provide an explanation.

One is that a Chinese national propaganda newspaper reported, only months after the bankruptcy commencement of Hanjin in South Korea, that the Chinese Shanghai Maritime Court took quick and effective actions in expediting around 16 lawsuits and subsequent enforcement against Hanjin in the interest of Shanghai International Port Limited, a Shanghai government-owned company, ${ }^{123}$ and of its subsidiaries, ${ }^{124}$ suggesting that at least in Shanghai the major beneficiaries of not recognising

\footnotetext{
117 Shi (2001).

118 Agence France Presse (1991) (reporting that most BCCI Chinese creditors are state-owned banks in China).

$119 \mathrm{Ke}(2014)$.

120 The High Court of Justice (Chancery Division), Notice Timeline for Hanjin Shipping Co., Ltd. (FC14777), Court Petitions and Orders: Cross-Border Insolvencies, The London Gazette, 13 September 2016.

121 Roberts (2017), p 18.

122 Song (2016).

123 See Shanghai International Port (Group) Co., Ltd. (2018), p 41.

124 Li and Huang (2017).
} 
Hanjin's South Korean bankruptcy proceeding were local state-owned companies. The Chinese Shanghai Maritime Court was portrayed as a national hero in safeguarding the interests of Shanghai local government-owned companies.

The second source is that a senior judge from the China Supreme People's Court honestly stated that if Hanjin's South Korean bankruptcy proceeding were recognised in China, it would have undermined the interests of COSCO (the China Ocean Shipping (Group) Company), a giant Chinese central government-owned company, which was the Chinese company that was most exposed in the Hanjin bankruptcy. ${ }^{125}$ This judge also noted that COSCO 'expressly indicated' that it did not want to see the recognition of the South Korean Hanjin bankruptcy proceeding in China, thereby implying how powerful COSCO is in shaping Chinese state/judicial decision-making. ${ }^{126}$

Given that the data above suggest that state-owned companies seem to be judicially untouchable, several interviewees were asked whether this reflects the true policy practised by Chinese courts. Three different voices from China can be summarised. First, a senior judge explained to the author that all companies, regardless of their ownership, are treated equally before the Chinese courts, and that no favour is reserved for state-owned companies. ${ }^{127}$ This is politically correct and is fully in line with what the Chinese law states, but this judge's comment does not match the data that this article has collected. Second, an interviewed lawyer doubted what can be concluded from the author's data, asserting that it might be purely coincidental that most denied foreign judgment recognition requests happen to have a Chinese state-owned company as an adversary. ${ }^{128}$ This interviewee's doubts could be correct, since, as shown in Table 2, probably the scale of the data is too small to support this article's interpretation, but it may be equally true that, like many Chinese people, this young lawyer is a victim of the Chinese propaganda machine which indoctrinates the masses with the notion that Chinese courts are always the best performers in delivering justice and fairness. ${ }^{129}$

Third, another interviewed lawyer largely agreed with the conclusion drawn from the data collected in this article, observing that if you read what is claimed in Chinese statutes, official media reports and government statements, all companies are treated equally, but in practice equal treatment raises concerns', ${ }^{130}$ implying that judicial favouritism for state-owned companies is still an issue in China. Nevertheless, state-owned companies in China are politically powerful, and, when seeking recognition in China, all foreign parties, including foreign bankruptcy representatives, must be aware of this. ${ }^{131}$ After state-owned companies, the presence of another group of parties should also be given special attention.

\footnotetext{
125 Song (2019), p 26.

126 Ibid.

127 Interview Qingdao-001 (Qingdao Shandong China, 1 August 2019).

128 Interview Qingdao-003 (Qingdao Shandong China, 1 August 2019).

129 See generally Shambaugh (2007), p 58.

130 Interview Shanghai-001 (Shanghai China, 13 August 2019).

131 See Brodsgaard (2012), p 638.
} 
The second of the five groups is state-linked companies. This article defines a state-linked company with reference to its influences on the local economy in general and local tax bases in particular, in addition to the company chairperson's political connections. This group contains only two companies, Jiangxi Province Lidu Fireworks Co., Ltd. (Lidu), which was the defendant in Herbert Truhe, et al $v$. Jiangxi Province Lidu Fireworks Co., Ltd., and Daoming Optics \& Chemical Co., Ltd. (Daoming), the defendant in Sase Tablissement Sacholiet v. Stetestrite International Co., Ltd. and Daoming Optics \& Chemical Co., Ltd.

Lidu was initially a local town government-owned company and was privatised years later, and its influence can be appreciated from its status as one of the 20 largest taxpaying companies in Nanchang, the capital city of the Chinese Jiangxi province, and the company's chairman, Mr Deng Qingmao, has on numerous occasions been appointed as a member of the local province's People's Congress, the Chinese local parliament. ${ }^{132}$ Therefore, this article confidently includes Lidu as a state-linked company.

Compared with Lidu, Daoming might be more influential. It is sufficiently powerful to be quoted on China's Shenzhen Stock Exchange, and unsurprisingly Daoming's chairman, Mr Hu Zhibiao, is also a member of the local Yongkang Municipal Political Consultation Committee, the equivalent of the upper house of parliament; ${ }^{133}$ in order to strengthen its connection with the government, Daoming has hired a young lawyer as its independent director ${ }^{134}$ whose father happens to be the deputy governor of Zhejiang province. ${ }^{135}$ Furthermore, Daoming is also officially deemed to be a substantial taxpaying company by the local government. ${ }^{136}$ Hence, it is reasonable to include Daoming as a state-linked company.

When facing a local state-linked company, as shown in Table 3 below, it seems as if the foreign judgment recognition applicant has a 50-50 chance of succeeding, since in the first Lidu case the application was rejected but the second Daoming one was successful. However, a further investigation finds that the second case, the Daoming case, eventually failed, since although the Chinese Jinghua Intermediate People's Court recognised the French judgment against Daoming in 2017, when the winning French company applied to have the judgment executed following recognition, the Jinghua Court surprisingly rejected it and the rejection order was later, very surprisingly, confirmed by the Chinese Zhejiang Province People's High Court in 2019 following an internal review. ${ }^{137}$ This means that, after years of legal wrangling, the French party returned home empty-handed. It is a final success for Daoming, but both the French party and China as a nation have to pay the price, with the former

\footnotetext{
132 Xiao (2017).

133 Daoming Optics \& Chemical Co., Ltd. (2014), p 4.

134 Daoming Optics \& Chemical Co., Ltd. (2019a), p 110.

135 The author is aware of the relationship between this female lawyer and her powerful father because of his law practice in Hangzhou, the capital city of Zhejiang province, which has operated for over a decade.

136 Daoming Optics \& Chemical Co., Ltd. (2017).

137 Daoming Optics \& Chemical Co., Ltd. (2019b), p 45.
} 
Table 3 The Fate of Foreign Judgment Recognition against State-Linked Companies in China. Source: Compiled by the Author

\begin{tabular}{lccc}
\hline Parties & Year & Financially affected party/defendant & Result \\
\hline $\begin{array}{l}\text { Herbert Truhe, et al v. Jiangxi Province } \\
\text { Lidu Fireworks Co., Ltd. }\end{array}$ & 2016 & $\begin{array}{c}\text { A former town government-owned } \\
\text { company }\end{array}$ & Rejected \\
$\begin{array}{l}\text { Sase Tablissement Sacholiet v. Stetestrite } \\
\text { International Co. Ltd. and Daoming }\end{array}$ & $\begin{array}{l}\text { A company listed at the Shenzhen Stock } \\
\text { Exchange }\end{array}$ & Recognised \\
\begin{tabular}{l} 
Optics \& Chemical Co. Ltd. \\
\hline
\end{tabular} & & \\
\hline
\end{tabular}

suffering financial losses and the latter incurring reputational damage in the long term.

Therefore, after taking into account the eventual failure of the Daoming case, it means that seeking judgment recognition against a local state-linked company is also more likely, if not bound, to fail. Like state-owned companies, many statelinked companies are also powerful enough to use the judicial system to shield them from any legal action, especially from overseas.

Is the difficulty facing foreign judgment recognition against a state-linked company in China also encountered by foreign bankruptcy judgment recognition efforts? The answer is not only yes, but is sometimes even more acute. The case of Wahaha v. KPMG epitomizes the struggle of foreign bankruptcy representatives when confronting powerful state-linked companies.

In Wahaha v. KPMG, the Chinese Jiangsu Province High People's Court ruled, in 2009, that two British Virgin Islands receivers had violated China's judicial sovereignty by acting on behalf of the foreign company in China without being recognised in the first place. ${ }^{138}$ Why were the two foreign bankruptcy representatives treated so harshly in China? The real reason might be that a state-linked company, Wahaha Group Limited, had become annoyed in this case. Wahaha Group Limited's influence in China, both economic and political, could be appreciated simply by reference to two facts: first, the company is China's largest beverage producer, ${ }^{139}$ and second, the company's chairman, Mr Zong Qinghou, has been continually acting as a member of the China People's Congress, the Chinese national parliament, for over 15 years. ${ }^{140}$

Like in the Liwan case, the Jiangsu Court also selectively chose to forget that Chinese law states that the legal status of foreign bankruptcy representatives representing foreign companies in bankruptcy could be automatically acknowledged in China. ${ }^{141}$ Why did the Jiangsu Court deliberately sow confusion? The

\footnotetext{
138 The Jiangsu Province High People's Court (2009) Suqian wahaha hengfeng yingliao youxian gongsi su bimawei huazhen kuaijishi shiwusuo jiqi guangzhou fensuo qingquan zeren jiufeng an (宿迁娃哈哈恒 枫饮料有限公司诉毕马威华振会计师事务所及其广州分所侵权责任纠纷案) [Suqian Wahaha Henfeng Beverage Limited v. KPMG (Hong Kong Office) and KPMG (Guangzhou Office)], Nanjing Jiangsu China, 28 April 2009, 2009 Su Min Er Zhong Zi Di 0045 Hao.

139 See Barboza (2009), p B8.

$140 \mathrm{Hu}$ (2017).

141 The China Supreme People's Court (1988) Guanyu guanche zhixing zhonghua renmin gongheguo minfa tongze ruogan wenti de yijian (关于贯彻执行中华人民共和国民法通则若干问题的意见) [The judicial opinions on implementing the China General Principles of Civil Law of 1986], http://www.lawlib.com/law/law_view.asp?id=203. Accessed 5 May 2020.
} 
well-connected businessman, Mr Zong Qinghuo, and his company's political connections, might be the answer.

Unlike the first two privileged groups of parties, the third group comprises foreign companies and individuals that are the intended target of a foreign judgment recognition and has four cases meeting this criterion. Usually these foreign parties either have assets located in China, as a result of which judgment creditors chase them to enforce the judgment against these assets, or are involved in a dispute connected with China. For example, in Spring Comm Co. Ltd. v. Park Joung Geun, both parties were from South Korea, and seeking the recognition of a judgment in China was mainly due to the judgment debtor having a valuable asset, an expensive flat worth some RBM10,000,000 (around US\$1,403,571), in the Chinese city of Shenzhen. ${ }^{142}$

As shown in Table 4 below, in this situation the Chinese courts seem to be considerably willing to grant recognition, since the recognition rate here is as high as 75\%: three received recognition and only one failed. In fact, the failed Spring Comm case could be omitted from the success rate calculation, since the lawyer representing Spring Comm Co., Ltd. informed the author that seeking a rejection was the aim of her South Korean client because the Chinese Shenzhen Intermediate People's Court did not allow the South Korean company to sue the defendant in China unless the South Korean initial judgment could be formally rejected by the Court; therefore, seeking a rejection was what Spring Common Co., Ltd. intended to achieve. ${ }^{143}$

Therefore, with the Spring Comm case being excluded, this means that if a foreign judgment recognition is to target a foreign party in China, its recognition is more likely to be $100 \%$ successful. This is also very likely to be true in foreign bankruptcy judgment recognition as evidenced in Re B\&T Ceramic Group S.R.L.

In Re B\&T Ceramic Group S.R.L., the Italian applicant petitioned the Chinese Foshan Intermediate People's Court to recognise the Italian court-confirmed bankruptcy asset sale plan by which all assets of the bankrupt company, E. N. Group s.p.a., were sold to the applicant; however, when the applicant travelled to China to claim one of the assets-shares in a Chinese joint venture, Nanhai Nassetti Ceramic Mechanics Limited-it found that the shares had been fraudulently sold to Broao Win International Limited, a Hong Kong company; after the Italian court-confirmed bankruptcy asset sale plan was recognised in China, the fraudulent share transaction was revoked and the shares were returned from Broao Win International Limited to the real owner, B\&T Ceramic Group S.R.L. ${ }^{144}$ Presumably, the result of this legal tussle might be different if Borao Win International Limited were a Chinese stateowned company.

The Chinese courts' 'generosity' or indifference to foreign bankruptcy recognition between foreign parties can also be seen in another case, Grace Young International Limited v. Seoil Agency Co., Ltd., which was heard in the Chinese city of Qingdao, in 2016. Seoil Agency Co., Ltd., a South Korean company, went through a bankruptcy rehabilitation procedure in South Korea in 2015, and its bankruptcy

\footnotetext{
${ }^{142}$ Interview Shenzhen-001 (Shenzhen Guangdong China, 17 December 2019).

143 Ibid.

144 Xinfu Law Firm (2001).
} 
Table 4 The Fate of Foreign Judgment Recognition against Foreign Companies or Individuals in China. Source: Compiled by the Author

\begin{tabular}{lccc}
\hline Parties & Year & Financially affected party/defendant & Result \\
\hline Re B\&T Ceramic Group S.R.L. & 2000 & $\begin{array}{c}\text { A Hong Kong company fraudulently } \\
\text { acquiring the assets of the bankrupt }\end{array}$ & Recognised \\
$\begin{array}{l}\text { Spring Comm Co. Ltd. v. Park Joung } \\
\text { Geun }\end{array}$ & 2011 & $\begin{array}{c}\text { Italian company in Foshan, China } \\
\text { A Korean individual having assets in } \\
\text { Shenzhen, China }\end{array}$ & Rejected \\
$\begin{array}{l}\text { Choi Jong Won v. Yoon Ji Young } \\
\text { Nalco Company LLC v. David Chen }\end{array}$ & 2018 & $\begin{array}{c}\text { A Korean individual having assets in } \\
\text { Qingdao, China }\end{array}$ & Recognised \\
& 2018 & $\begin{array}{c}\text { An American individual having assets } \\
\text { in Shanghai, China }\end{array}$ & Recognised \\
\hline
\end{tabular}

rehabilitation plan was voted upon by the creditors and was approved by the court in June 2016; however, one of the South Korean bankruptcy rehabilitation plan creditors, Grace Young International Limited, a British Virgin Islands company, saw an opportunity in September 2016 to circumvent the South Korean debt restructuring plan, which paid the creditors 31 cents on the dollar, by seizing a vessel owned by Seoil Agency Co., Ltd. passing through the Chinese Qingdao waters, in order to obtain a full debt payment. ${ }^{145}$

In dealing with this dispute, the Chinese Qingdao Maritime Court actually faced a dilemma: Allowing the British Virgin Islands creditor to seize the vessel would be unfair to other creditors bound by the South Korean debt restructuring plan, but refusing the plaintiff's petition would be a de facto recognition of the South Korean bankruptcy rehabilitation plan in China, which is legally implausible as there is no treaty between China and South Korea and as there is no established reciprocity (this is incorrect, as examined in this article) between the two countries.

To prevent the British Virgin Islands creditor from unfairly taking advantage of this legal loophole, the Chinese Qingdao Maritime Court still rejected the petition in 2017 but on the grounds that China is an inconvenient place to settle the dispute between two foreign parties, which is a de facto recognition of the South Korean bankruptcy rehabilitation plan. ${ }^{146}$ Justice was served, since the disputing parties were foreigners, and the inconvenient court principle was intended to fill the gap. However, in the following similar case in 2017, another Chinese court, the Chinese Ningbo Maritime Court, ironically forgot the inconvenient court principle.

COSCO Shipping Development (Hong Kong) Limited, a company registered in Hong Kong and legally treated as a foreign company in China, was a creditor of Hanjin Shipping Co., Ltd. whose global insolvency has been discussed earlier in this article; in their service contract, both sides had agreed to be bound by English law and any disputes would be dealt with before the London High Court; as said before, given that Hanjin's South Korean bankruptcy proceeding was recognised in the UK

\footnotetext{
145 Zhao (2017), p 104.

146 The Chinese Qingdao Maritime Court (2019) Minshi caiding shu (民事裁定书) [Civil court order], 2006 Lu 72 Min Chu 2019 Hao.
} 
in 2016 and a general moratorium was accordingly imposed, the Hong Kong company could not sue Hanjin in London. ${ }^{147}$

However, similar to what was done by the British Virgin Islands company, Grace Young International Limited, in Qingdao in 2016, COSCO Shipping Development (Hong Kong) Limited also identified an opportunity in China in 2017, since Hanjin owned valuable equity in a Chinese subsidiary domiciled in Ningbo, Zhejiang Province; both parties in this case were foreigners; allowing the Hong Kong company to seize Hanjin's assets in China would be apparently unfair to other creditors who were unable to take legal action in the UK or in Korea and had to file claims in the South Korean bankruptcy procedure, but the Ningbo Court, on this occasion, happened to forget the inconvenient court principle practised by its fellow court, the Chinese Qingdao Maritime Court, and supported the claim of the Hong Kong company. ${ }^{148}$ This meant that no de facto recognition of the South Korean bankruptcy proceeding was made on this occasion. Why did the Chinese Ningbo Maritime Court behave totally differently from its fellow court? The reason that many did not want to disclose is that COSCO Shipping Development (Hong Kong) Limited, in spite of being registered in Hong Kong, is a wholly-owned subsidiary of COSCO Shipping Development Limited, a giant Chinese central government-owned company. ${ }^{149}$ What lies at the heart of Chinese judicial decision-making is not justice or fairness, instead the determining factor here is the party's relationship with the Chinese state.

What can be learnt from the COSCO case could also reinforce the conviction generated from the previous two groups of cases regarding favouritism towards state-owned and state-linked companies. Now, attention moves to another group of affected parties.

The fourth group contains Chinese ordinary companies that are not state-owned or state-linked and are the financially affected parties in foreign judgment recognitions. In order to include the companies in this group, this article generally looks at three criteria: The amount of the company's registered capital, which is relatively small, whether the company is a former state-owned one, and whether the company's chairman or CEO occupies political positions. For instance, in Przedsiebiorstwo Przemyslu Chlodniczego Fritar S.A., Poland v. Ningbo Yongchang Industry Company, the financially-affected party was Ningbo Yongchang Industry Company whose registered capital was only RMB 7,030,000 (some US\$984,000), and which is a typical small and medium-sized enterprise; ${ }^{150}$ the company was never a stateowned company; the chairperson of the company, Lei Qiuhai, is invisible on the Internet, suggesting that it is very unlikely for him/her to play any political role at the local or national level; therefore, the company could be labelled as an ordinary

\footnotetext{
147 The Chinese Ningbo Maritime Court (2017) Minshi panjue shu (民事判玦书) [Civil court judgment], 2017 Zhe 72 Min Chu 1761 Hao.

148 Ibid.

149 COSCO Shipping Development Co., Ltd. (2020) Zhongyuan haiyun fazhan gufen youxian gongsi zuzhi jiagou (中远海运发展股份有限公司组织架构) [Structure of the company], http://development. coscoshipping.com/col/col1553/index.html. Accessed 3 June 2020.

150 The China National Enterprise Registration Disclosure System (2020) Ningbo shi yongchang gongmao shiye gongsi (宁波市角昌工贸实业公司) [Ningbo Yongchang Industry Company], http://zj.gsxt. gov.cn/corp-query-search-1.html. Accessed 28 May 2020.
} 
private company in China. According to these standards, there are eight cases that can be included in this group, as listed in Table 5.

As outlined in Table 5, of these eight cases, there were five failed recognition efforts and the remaining three were successful, suggesting that if a foreign judgment recognition turns against an ordinary Chinese company there is a $37.5 \%$ chance of succeeding. It still appears to be considerably difficult. A further examination finds that out of the three successful cases there are two cases, Emre Gida Insaat Sanayi ve Ticaret Limited Sirketi v. Jining Xingchen Textile Import \& Export Co., Ltd. (the Emre case) and Haweisitetayimu Co,. Ltd. v. Daqiaofang Food Co., Ltd. (the Haweisitatayimu case), in which the foreign party was actually given an empty recognition order. Why?

In the Emre case, the original Turkish commercial judgment took effect on 28 April 2007, and it remains unknown how hard the Turkish company fought through and eventually persuaded the Chinese Jining Intermediate People's Court to open a judgment recognition procedure; unfortunately, when the Turkish court judgment was finally recognised in China in $2014,{ }^{151}$ the Chinese company, Jining Xingchen Textile Import \& Export Co., Ltd., which owed a US\$103,000 judgment debt to the Turkish party, had already been dissolved in $2010 .{ }^{152}$ This suggests that in a financial sense the victory by the Turkish party in the Emre case is largely meaningless, since the recognised judgment could not be effectively executed because of the disappearance, legal and physical, of the judgment debtor in China.

A similar result also occurred in the Haweisitatayimu case: The Russian company, Haweisitatayimu Co., Ltd., struggled for almost a year at the Chinese Chifeng Intermediate People's Court and finally received the recognition result late in $2018{ }^{153}$ however, since as early as in 2016 the judgment debtor, Daqiaofang Food Co., Ltd., had been placed, on at least seven occasions, on China's national judicial blacklist for being unable to honour judgment debts. ${ }^{154}$ This meant that the Russian company was also more or less given a shallow victory, because no money would be recovered.

Hence, if the Emre and Haweisitatayimu cases are not taken into consideration, it means that out of the remaining six cases there was only one successful recognition, suggesting a substantial recognition success rate of $16.7 \%$ in this situation. But given that these companies are politically powerless in demanding a favour from the Chinese judicial system, why are they, it seems, still favourably treated? The possible explanation could be that the Chinese regime mainly collects tax from companies, ${ }^{155}$ as a result of which companies, regardless of their ownership, are well-guarded tax

\footnotetext{
151 Zhao (2014).

152 The Chinese Jining Intermediate People's Court (2013) Minshi caiding shu (民事裁定书) [Civil court order], 2013 Ji Min San Chu Zi Di 124 Hao.

153 The Chinese Chifeng Intermediate People’s Court (2018) Minshi caiding shu (民事裁定书) [Civil court order], 2018 Nei 04 Xie Wai Ren 1 Hao.

154 The China Supreme People's Court (2016) Neimenggu daqiaofang shipin youxian zeren gongsi (内蒙古大荞坊食品有限责任公司) [Daqiaofang Food Co. Ltd], http://zxgk.court.gov.cn/zhongben/. Accessed 29 May 2020.

155 See Haitong Securities Co., Ltd. (2018).
} 
Table 5 The Fate of Foreign Judgment Recognition against Chinese Ordinary Companies in China. Source: Compiled by the Author

\begin{tabular}{|c|c|c|c|}
\hline Parties & Year & Financially affected party/defendant & Result \\
\hline $\begin{array}{l}\text { Gomi Akira v. Japanese-Chinese Prod- } \\
\text { ucts Co., Ltd. }\end{array}$ & 1994 & A foreign-invested company in Dalian & Rejected \\
\hline $\begin{array}{l}\text { Schneider Electric SA v. Wenzhou Flying- } \\
\text { Dragon Electrical Co., Ltd. }\end{array}$ & 2005 & A foreign-invested company in Wenzhou & Rejected \\
\hline $\begin{array}{l}\text { Hukla Matratzen GmbH v. Beijing Fukela } \\
\text { Furniture Selling Co., Ltd. }\end{array}$ & 2010 & A private company in Beijing & Rejected \\
\hline $\begin{array}{l}\text { Przedsiebiorstwo Przemyslu Chlodnic- } \\
\text { zego Fritar S.A., Poland v. Ningbo } \\
\text { Yongchang Industry Company }\end{array}$ & 2011 & A private company in Ningbo, & recognised \\
\hline $\begin{array}{l}\text { Choryanaslzizmat Limited v. Haihong } \\
\text { Trade Co., Ltd. }\end{array}$ & 2011 & A private company in Khorgas, & Rejected \\
\hline $\begin{array}{l}\text { Uzprommashimpeks v. Wenzhou Jinshi } \\
\text { Entertainment Apparatus Manufactur- } \\
\text { ing Co., Ltd. }\end{array}$ & 2013 & A private company in Wenzhou & Rejected \\
\hline $\begin{array}{l}\text { Emre Gida Insaat Sanayi ve Ticaret Lim- } \\
\text { ited Sirketi v. Jining Xingchen Textile } \\
\text { Import \& Export Co., Ltd. }\end{array}$ & 2013 & A private company in Jining & Recognised \\
\hline $\begin{array}{l}\text { Haweisitetayimu Co. Ltd. v. Daqiaofang } \\
\text { Food Co., Ltd }\end{array}$ & 2018 & A private company in Chifeng & Recognised \\
\hline
\end{tabular}

bases and anyone who wants to take a bite will be chased away by the ruling class, a part of which is the Chinese judicial sector. Unfortunately, this article is unable to find a foreign bankruptcy judgment recognition case to illustrate whether foreign bankruptcy representatives may face similar challenges if the adversary is a Chinese ordinary company.

The final group is made up of Chinese individuals/nationals that are financially affected parties and contains six cases, as listed in Table 6. On the face of it, the recognition success rate, or so it appears, is pretty high, since four out of six received recognition, suggesting a success rate of $66.7 \%$. A closer inspection finds that both of the two rejected applications involved a foreign company turning against Chinese individuals. In DNT France Power Engine Co., Ltd. v. Zhen Xiyong (the DNT case), the applicant, DNT France Power Engine Co., Ltd., was an Australian company, and the defendant, Mr Zhen Xiyong, was a Chinese national living in Shenzhen. ${ }^{156}$ In $S$. L. Jonas Co., Ltd. v. Yang Ping (the Jonas case), the applicant, S. L. Jonas Co., Ltd.,

\footnotetext{
156 The China Supreme People's Court (2007) Guanyu shenqingren fuolaxi dongli fadongji youxian gongsi shenqing chenren he zhixing aodaliya fayuan panjue yi'an de qingshi de fuhan (关于申请人弗 拉西动力发动机有限公司申请承认和执行澳大利亚法院判决一案的请示的复函) [A reply to the request concerning whether the Australian judgment could be recognised in China upon the application of DNT France Power Engine Co., Ltd.], 2006 Min Si Ta Zi Di 45 Hao.
} 
Table 6 The Fate of Foreign Judgment Recognition against Chinese Individuals in China. Source: Compiled by the Author

\begin{tabular}{|c|c|c|c|}
\hline Parties & Year & Financially affected party/defendant & Result \\
\hline $\begin{array}{l}\text { DNT France Power Engine Co., Ltd. v. Zhen } \\
\quad \text { Xiyong }\end{array}$ & 2006 & A Chinese individual & Rejected \\
\hline Re Sascha Rudolf Seehaus & 2012 & $\begin{array}{l}\text { A Chinese individual in control of a } \\
\text { German company's subsidiary in } \\
\text { China }\end{array}$ & Recognised \\
\hline Li Liu v. Li Tao \& Wu Tong & 2015 & Two Chinese individuals & Recognised \\
\hline $\begin{array}{l}\text { Zhu Jing, Ding Changhong and Zhu Guofen } \\
\quad \text { v. Pei Yanju }\end{array}$ & 2016 & A Chinese individual & Recognised \\
\hline Li Xianming v. Tian Fei & 2017 & A Chinese individual & Recognised \\
\hline S. L. Jonas Co., Ltd. v. Yang Ping & 2017 & A Chinese individual & Rejected \\
\hline
\end{tabular}

was an Israeli company, and the judgment debtor was a Chinese individual residing in Fuzhou. ${ }^{157}$

Hence, it seems that being a foreign company acting against a Chinese individual might be a disadvantage when seeking judgment recognition in China. By contrast, it is very interesting to find that in all three judgment recognitions between Chinese individuals, Li Liu v. Li Tao \& Wu Tong, Zhu Jing, Ding Changhong and Zhu Guofen v. Pei Yanju, and Li Xianming v. Tian Fei, the recognition application was successful. This means that in the event that a legal dispute takes place between Chinese individuals but is adjudicated overseas, it is very likely for the foreign judgment to be recognised and enforced in China.

In the DNT and Jonas cases, the foreign party suffered a defeat, but in a similar case, Re Sascha Rudolf Seehaus, the foreign bankruptcy representative, Mr Sascha Rudolf Seehaus from Germany, successfully obtained the recognition of the German bankruptcy judgment, which authorised him to represent the German company in bankruptcy to take control of its wholly-owned subsidiary in China; ${ }^{158}$ in this case, the de facto adversary was a Chinese individual, Mr Chen Lin, who was the CEO of the Chinese subsidiary and refused to surrender control of the company. ${ }^{159}$ However, as will be examined later, the court's recognition in this case was useless, since the dispute against the Chinese individual had already been resolved before the court issued the recognition order. Therefore, if Re Sascha Rudolf Seehaus is not considered here, the situation appears to be glum since recognition is bound to fail if it involves a foreign party (a company or an individual) acting against a Chinese individual.

Overall, as for the challenges facing a foreign bankruptcy representative seeking assistance from China, at least there are three apparent lessons that could be learned from what has been summarised from the data presented here. First, when the Chinese adversary/opponent is a formidable state-owned company, it is very unlikely

\footnotetext{
157 See Zhu (2018), pp 212-213.

158 Interview Wuhan-002 (Wuhan Hubei China, 9 August 2019).

159 The China Supreme People's Court (2015) Zaishen minshi caiding shu (再审民事裁定书) [Retrial civil court order], 2015 Min Shen Zi Di 537 Hao.
} 
for a foreign bankruptcy representative to obtain judicial assistance. ${ }^{160}$ Second, if the Chinese adversary is a state-linked company, the possibility of obtaining judicial assistance from China is also slim. Third, for a foreign bankruptcy representative, if the 'trouble maker' happens to be a foreigner as well, the recognition effort is likely to succeed.

After clearing the three aforementioned major hurdles, a foreign bankruptcy representative must be prepared for the next stumbling block.

\subsubsection{The General Hostility of the Chinese Courts Towards Foreign Judgment Recognition}

Many Chinese courts, it seems, are considerably averse to foreign judgment recognition issues, including foreign bankruptcy judgment decisions. ${ }^{161}$ Such hostility can be observed in two forms.

First, it is very difficult to persuade Chinese courts to officially open a foreign judgment recognition procedure. Without being allowed to enter a courtroom, recognition is killed off before it can even be considered. This situation can be attributed to both the design of the law and the development of the law courts in China. Like many Chinese laws that rarely hold public authorities accountable, the China Civil Procedure Law 1991 Articles 281 and 282 stipulate that a foreign judgment recognition petition should be lodged at a local intermediate people's court, but there is no article or provision in this statute or its related judicial notices made by the China Supreme People's Court that require that local courts must register the petition, and if not, how court officials should be held to account. This inevitably opens the floodgates for abuse.

The author met many practitioners during the 2019 fieldwork in China, many of them angered by the courts' inactivity in registering a foreign judgment recognition petition in the first place. The lawyer representing the first American judgment recognised in the Chinese Wuhan Intermediate People's Court recalled that to procedurally register the recognition petition took him over a month since the court initially refused to accept the application and that, following intense negotiation and protests, the court finally decided to hear the case only after approval by the court's internal decision-making body, the judicial committee, and after consulting its superior court, the Chinese Hubei Province High People's Court; he further commented that in general the court is very cautious in dealing with foreign judgment recognitions, adding that after his success he received many telephone queries from fellow lawyers in Shenzhen, Shanghai and Qingdao asking how he had persuaded the Wuhan Court to accept the petition since they had all failed to have their petition registered. ${ }^{162}$ This lawyer's observation is clear: he was very lucky, but most recognition petitions would not be allowed to be officially considered at all.

The lawyer dealing with the recognition case in Spring Comm Co., Ltd. v. Park Joung Geun was still angry when talking with the author in December 2019,

\footnotetext{
${ }^{160}$ Clarke (2017).

161 Li (2019), p 1071.

162 Interview Wuhan-001 (Wuhan Hubei China, 8 August 2019).
} 
recounting that the court officials told her bluntly that they did not consider foreign judgment recognition issues since they did not have the necessary experience, and that, following around one week of nerve-racking protest and persuasion, the court ultimately agreed to register the application. ${ }^{163}$ A similar response can also be heard from another city, where a senior lawyer, involved in Choi Jong Won v. Yoon Ji Young, stated that he had engaged in about two hours of bitter verbal exchanges with the court officials when trying to register the petition, but the court still refused to do so; and days later, when the court surprisingly informed him that the court had agreed to open the procedure, he had to ask his assistant to complete the court registration issues because of his soured relationship with the court officials after the two-hour quarrel some days previously. ${ }^{164}$

A senior judge in charge of foreign disputes admitted that refusing foreign judgment recognition petitions is convenient for the courts, but to recognise a foreign judgment is too complicated, thereby in principle refusing to recognise is the default answer from the point of view of the law courts. ${ }^{165}$ Although this judge did not elaborate as to why recognising a foreign judgment is too complicated for the courts, probably, as noted before, it is because most recognition decisions should be internally agreed by a superior court, and even sometimes by the China Supreme People's Court, which is also a formidable task for judges.

It is fair to say that many, if not most, Chinese judges might not be well versed in dealing with foreign judgment recognitions. One example highlights this where, according to one lawyer, the judges dealing with the Spring Comm case did not even know whether China has a judicial assistance treaty with South Korea. ${ }^{166}$

Hence, there seems to be a vicious cycle: few foreign judgment recognition cases in China lead to judges having little experience therewith, and inexperienced judges cite their lack of experience in refusing to hear foreign judgment recognition petitions, which is then followed by even fewer cases. But this article is nevertheless rather optimistic, since given the ongoing globalisation of China, more foreign judgment recognition demands will arise, and the Chinese court system has no option but to respond to the changing world.

Inevitably, the challenge of opening a foreign judgment recognition procedure is also faced by foreign bankruptcy representatives seeking judicial assistance in China. For instance, regarding Hanjin's treatment in China, although Hanjin's Chinese lawyer refused to say whether Hanjin did submit a bankruptcy judgment recognition in China, ${ }^{167}$ presumably Hanjin might also have failed to have its bankruptcy recognition petition registered, as in many cases examined above.

Second, the hostility can be observed from the fact that some Chinese courts deliberately ignore the existence of reciprocity and some foreign judgment recognition petitions are thereby arbitrarily rejected. The typical example is the Lidu case,

\footnotetext{
163 Interview Shenzhen-001 (Shenzhen Guangdong China, 17 December 2019).

164 Interview Qingdao-002 (Qingdao Shandong China, 2 August 2019).

165 Interview Qingdao-001 (Qingdao Shandong China, 1 August 2019).

166 Interview Shenzhen-001 (Shenzhen Guangdong China, 17 August 2019).

167 Interview Shanghai-003 (Shanghai China, 9 August 2019).
} 
in which the applicant presented evidence that reciprocity had been established between China and the USA, even by Chinese restrictive standards, but the Chinese Nanchang Intermediate People's Court still rejected the application on the basis that there was no reciprocity. ${ }^{168}$ In fact, the Nanchang Court is not the only undisciplined court. In Re Zhang Xiaoxi, ${ }^{169}$ S. L. Jonas Co., Ltd. v. Yang Ping, ${ }^{170}$ and Hukla Matratzen GmbH v. Beijing Fukela Furniture Selling Co., Ltd., ${ }^{171}$ the courts in Shenyang, Fuzhou and Beijing also did not respond, either intentionally or inadvertently, to the applicants' claim that reciprocity existed with South Korea, Israel and Germany respectively.

Arguably, if Hanjin had applied for recognition in China by providing evidence of the existence of reciprocity between China and South Korea, it remains unknown whether a court in China would have repeated its lack of discipline. Nevertheless, some courts' behaviour is considerably disappointing, thereby undermining the creditability of the Chinese court system as a whole. Needless to say, for a foreign bankruptcy representative, understanding the misbehaviour of the Chinese courts in this regard would be critical in some circumstances.

Overall, the findings of these four hurdles/factors could largely explain why there are few foreign bankruptcy recognition cases in China and the major elements obstructing the recognition efforts of foreign bankruptcy representatives. But in view of the three successful bankruptcy recognition cases which have taken place in China, the question is whether these cases indeed mark a development in China's cross-border insolvency law and are worth celebrating.

\subsection{The Widely-Cited But Useless Foreign Bankruptcy Judgment Recognition Precedents in China}

Many often quote the three foreign bankruptcy judgment recognition cases, $R e B \& T$ Ceramic Group S.R.L., Re Pellis Corium PELCOR and Re Sascha Rudolf Seehaus, to either interpret or celebrate China's cross-border insolvency law development. However, this article finds that upon closer examination, unfortunately, no progress has been made at all.

According to the Model Law, this article is of the view that genuine judicial assistance entails recognising foreign bankruptcy judgments and to grant, more significantly, a general moratorium barring individual creditors' actions in the domestic jurisdiction, and to open a secondary procedure, if applicable, to assist the foreign

\footnotetext{
168 He (2018), p 1144.

169 Chen and Jiang (2018), p 19.

170 See Xu (2018).

171 The China Supreme People's Court (2010) Guanyu shenqing chenren ji zhixing deyizhi lianbang gongheguo aofenbao zhou fayuan ti 20460/07 panjue yi'an de qingshi de fuhan (关于申请承认及执 行德意志联邦共和国奥芬堡州法院第20460/07判决一案的请示的得函) [A reply to the instruction request on the application for the recognition (and enforcement) of judgment 20460/07 of the Offenburg Court in the Federal Republic of Germany], 2010 Min Si Ta Zi Di 81 Hao.
} 
(main) bankruptcy procedure. Measured against these yardsticks, China's cross-border insolvency law has made no progress before and after the promulgation of the EBL 2006.

This is because the purpose of all three existing foreign bankruptcy judgment recognition cases is essentially to ask the court to recognise the legal status of the foreign bankruptcy representative, which should have been automatically acknowledged under Chinese law but is, unlawfully, not accepted by China's government agencies. These three cases can prove how lawless China's government agencies are, rather than proving China's progress on cross-border insolvency law.

First, in Re Sascha Rudolf Seehaus, the most recent foreign bankruptcy judgment recognition in China, the Wuhan Court was approached by the German liquidator, because the Wuhan Municipal Government Business Department had declined to recognise that Mr Seehaus could act on behalf of the German company, as a result of which Mr Seehaus could not legally register the board member changes of the wholly-owned subsidiary in Wuhan so as to remove uncooperative board members who hampered the sole shareholder's control effort. ${ }^{172}$ To cover its own legal ignorance, the Wuhan Municipal Government Business Department required that the German liquidator had to get the German bankruptcy judgment, which appointed him as the liquidator, recognised by the Chinese Wuhan Intermediate People's Court. $^{173}$

Thankfully, the Wuhan Court finally issued a supportive recognition court order in 2013. Ironically, long before obtaining the court's recognition, early in 2011, the China National Business Ministry issued, in response to the German liquidator's complaints and threats to bring China to an international foreign investment dispute arbitration tribunal, a special note stating that the legal status of the German liquidator representing the German company should be automatically allowed and that court recognition was unnecessary. ${ }^{174}$ With this note, the German liquidator successfully changed the board members of the company's subsidiary and officially registered the changes at the Wuhan Municipal Business Department on 2 April 2011, which subsequently triggered the board membership replacement registration at another local government agency, the Wuhan Municipal Business Entity and Market Supervision and Management Bureau. ${ }^{175}$ This meant that the tardy recognition from the Wuhan Court was useless from the point of view of the German liquidator.

It is worth noting that when deciding to grant recognition to the German bankruptcy judgment, to the disappointment of some Chinese bankruptcy

\footnotetext{
172 The Chinese Wuhan Intermediate People's Court (2012) Minshi caiding shu (民事裁定书) [Civil court order], 2012 E Wuhan Zhong Min Shang Wai Chu Zi Di 00016 Hao.

173 The China Supreme People's Court (2015) Zaishen minshi caiding shu (再审民事裁定书) [Retrial civil court order], 2015 Min Shen Zi Di 537 Hao.

${ }^{174}$ Interview Wuhan-002 (Wuhan Hubei China, 9 August 2019).

175 The China Supreme People's Court (2015) Zaishen minshi caiding shu (再审民事裁定书) [Retrial civil court order], 2015 Min Shen Zi Di 537 Hao.
} 
scholars, ${ }^{176}$ the Wuhan Court relied on Article 282 of the China Civil Procedure Law 1991, a provision generally used to recognise foreign civil and commercial judgments, rather than Article 5 of the EBL 2006, which is a tailor-made provision for recognising foreign bankruptcy judgments. This suggests that Article 5 of the EBL 2006 could be neglected when recognising foreign bankruptcy judgments, which reinforces this article's view that Article 5 of the EBL 2006 was simply copied and pasted from Article 282 of the China Civil Procedure Law 1991 and no substantial legislative progress was made by the enactment of the new bankruptcy statute in China.

Second, in Re Pellis Corium PELCOR, it was almost the same story. The French liquidator, Mr Antoine Montier, was told by the Chinese Guangzhou Property Management Bureau, which is in charge of property registration, that he was not allowed to represent the French company, Societe Anonyme PELLIS CORIUM PELCOR, in registering the sale of the company's real estate located in Guangzhou unless the French bankruptcy judgment appointing the liquidator could be recognised by the Chinese Guangzhou Intermediate People's Court. ${ }^{177}$ Whether or not this demand was legal, the French liquidator had little choice but to follow it, otherwise he could not dispose of the company's real property in China.

Third, the case of Re B\&T Ceramic Group S.R.L. also emerged because of the misbehaviour of a Chinese government agency. On 24 October 1997, the Italian company, E. N. Group s.p.a., entered into a bankruptcy procedure and therefore the company's assets came under the control of the bankruptcy liquidator. However, during the bankruptcy procedure, on 2 May 1999, one of the company's assets, 98\% of the shares in a Chinese joint venture, was fraudulently sold to a Hong Kong company by the company's former managers. When the Italian bankruptcy assets' purchaser, B\&T Ceramic Group S.R.L, requested the Chinese Foshan Nanhai Foreign Business and Trade Bureau to revoke the fraudulent transaction, it was informed that the Italian bankruptcy judgment and its court-confirmed assets sale plan had to be recognised by the Chinese Foshan Intermediate People's Court. At the heart of this case was whether the Italian liquidator had an exclusive right in disposing of the company's assets, namely whether the liquidator's legal status could be recognised in China. This case is yet another example of a government agency refusing to recognise the legal status of a foreign bankruptcy representative.

Hence, all of these three cases have one common feature: the legal status of foreign bankruptcy representatives is not recognised by Chinese government agencies. In view of these three cases, arguably, China has never taken a substantial step in recognising a foreign bankruptcy judgment and subsequently granting a moratorium. There have been many occasions when the Chinese courts could do so. For example, Hanjin provided a golden opportunity in 2016. Given that reciprocity had

\footnotetext{
176 Shi and Huang (2017), p 41.

177 Antoine Montier (2004) Shenqingshu, qingqiu chenren faguo puwa ti'er shangye fayuan de caijue (申请书: 请求承认法国普瓦提艾商业法院的裁决) [Application for the Recognition of the Bankruptcy Judgment Rendered by the French Poitiers Commercial Court]. The photocopied application form was kindly provided by a judge from the Chinese Guangzhou Intermediate People's Court in December 2019 when the author did his fieldwork in Guangzhou.
} 
been established between China and South Korea, albeit according to Chinese standards, China could have used this opportunity to fill many gaps left by the vague and skeletal Article 5 of the EBL 2006, but due to the vested interests of state-owned companies, China's courts chose not to take a first step.

Cross-border insolvency is a two-way street. Although it is very difficult for foreign bankruptcy judgments to be recognised and assisted in China, it might be a different story when Chinese bankruptcy judgments seek cooperation abroad.

\subsection{Chinese Bankruptcy Judgments Seeking Recognition Overseas}

There are two widely studied cases. The first is the Chinese bankruptcy judgment in Guangdong International Trust \& Investment Corporation (GITIC) recognised in Hong Kong in 1999, a time before the promulgation of the EBL 2006. ${ }^{178}$ By recognising the Chinese bankruptcy judgment, the Hong Kong Court rejected the litigation and asset seizure of a local creditor, instructing the local creditor to register the claim with the liquidator in China instead. ${ }^{179}$ To the surprise of many Chinese scholars, the Hong Kong Court did not require the fulfilment of a treaty or reciprocity when recognising a foreign bankruptcy judgment, and the court simply exercised its judicial discretion in the interest of fairness when granting recognition to the Chinese bankruptcy judgment. ${ }^{180}$

The second case occurred after the enactment of the EBL 2006. In 2014, the Chinese bankruptcy reorganization procedure of Zhejiang Topoint Photovoltaic Co., Ltd. was recognised by the New Jersey District Bankruptcy Court, in the USA, as a result of which the local creditor's action in seizing the company's assets located in the USA was rejected; unlike the Chinese courts, the New Jersey court granted recognition and the subsequent relief, under Chapter 15 of the American Bankruptcy Code, purely in the belief that it was fair to do so, otherwise the American creditor would have unfairly taken advantage of the location of the Chinese company's assets to the detriment of the general body of creditors that were bound by the collective bankruptcy procedure in China. ${ }^{181}$ The pursuit of fairness is what many Chinese courts do not prioritise, unfortunately.

Generally speaking, it is fairly easy for Chinese bankruptcy judgments to be recognised abroad, especially in those countries that have adopted the Model Law. Many jurisdictions, like the UK, the USA and Australia, do not require a treaty or the existence of reciprocity when deliberating on the recognition of foreign judgments, including foreign bankruptcy judgments. The fact that many Chinese commercial

\footnotetext{
178 CCIC Finance Ltd. v. Guangdong International Trust \& Investment Corp. and Guangdong International Trust and Investment Corp Hong Kong (holding) Ltd (Garnishee) 2005 WL 1608158, [2005] HKEC 1180.

179 Ibid.

$180 \mathrm{Bu}$ (2009), p 190.

181 In Re Zhejiang Topoint Photovoltaic Co., Ltd. [2015] United State Bankruptcy Court for the District of New Jersey Case No. 14-245-249.
} 
judgments have been recognised in the USA, the UK, ${ }^{182}$ Australia, Israel, and Germany ${ }^{183}$ in recent years could serve as a strong signal.

Hence, this article is of the view that China's participation in globalised crossborder insolvency is more or less a one-way street: seeking judicial bankruptcy assistance from China is generally quite difficult, but for Chinese bankruptcy representatives, such assistance from developed jurisdictions is generously available. Given that China is still at the early stages of the rule of law development, it may take decades for China to catch up.

\section{Conclusion}

Although China has sent a clear legislative message in the EBL 2006 Article 5 to promote cross-border insolvency collaboration, little progress has been made on the ground. Article 5 of the EBL 2006 remains a dead letter, since it has had no effect on assisting the judicial recognition of foreign bankruptcy judgments.

In light of the findings in this article, several key points are worth summarising. First, China's cross-border insolvency development is largely paralysed by the rigid requirement of a treaty or reciprocity between China and requesting countries, and this might be the key reason for the scarcity of cross-border bankruptcy recognition cases in China. Second, to make the dire situation worse, many Chinese courts silently engage in local protectionism as far as the short-term interests of stateowned and state-linked companies are concerned, which undermines foreign parties' faith in seeking judicial assistance from China and adversely affects the development of China's cross-border insolvency law.

Third, although there are signs of a thaw, as evidenced by the three successful foreign bankruptcy judgment recognitions, this article finds that they amount to false progress, since all three recognition court orders are essentially superfluous and were only delivered in order to meet unlawful demands by law-breaking Chinese government agencies. It is not an exaggeration to say that there has been no substantial progress in developing China's cross-border insolvency system. Fourth, on the contrary, for a Chinese bankruptcy judgment, the bankruptcy representative could fully take advantage of the liberal judicial infrastructure, especially of developed jurisdictions, to obtain assistance, thereby reinforcing this article's central theme: China's participation in globalised cross-border insolvency amounts to nothing more than a one-way street. ${ }^{184}$

As for policy recommendations, first, China should abandon the current legal requirement of a treaty or reciprocity when deliberating foreign bankruptcy recognition requests, since China's current cross-border insolvency collaboration system is not in line with general international practice in the $21^{\text {st }}$ century. Second, given

\footnotetext{
182 Spliethoff's Bevrachtingskantoor BV v. Bank of China Limited [2015] EWHC 999 (Comm) (London High Court recognised a Chinese commercial judgment in 2013).

${ }^{183}$ Zhang (2017), pp 523-524.

${ }^{184}$ See Brattberg and Corre (2020).
} 
the widespread local protectionism in China and the relatively small number of foreign (bankruptcy) judgment recognition demands at present, allocating these cases to provincial high people's courts should be the short-term solution. By doing so, it is also easier to train a smaller group of judges. Third, the EU and the USA should keep on using the platforms of, among others, the World Trade Organization and the G20 summits to put pressure on China with a view to further legal reforms in China.

Returning to the global endeavour of promoting modified universalism across the world, this article's findings from China suggest that more should be done to persuade developing countries to join the international community so as to promote efficiency and safeguard fairness. China and everyone else have a long way to go.

Acknowledgement This work was supported by the UK Economic and Social Research Council [ES/ P004040/1]. The author wishes to thank Professor Gerard McCormack for his comments on early drafts of this article. This article has also considerably benefited from an ad hoc seminar organized by the Chinese Guangdong Province Supreme People's Court in December 2019, and the author thanks Professor Xu Yangguang and Mr Justice Guo Yiming for arranging this seminar which was attended by some top insolvency practitioners from both Guangdong and Hong Kong. The author also wishes to thank Zhang Mary Yuhe, his personal research assistant, for her linguistic support in correcting the pinyin names of the Chinese companies investigated in this article, and her Mandarin excellence is well appreciated. All errors and mistakes in this article remain the author's sole responsibility.

Open Access This article is licensed under a Creative Commons Attribution 4.0 International License, which permits use, sharing, adaptation, distribution and reproduction in any medium or format, as long as you give appropriate credit to the original author(s) and the source, provide a link to the Creative Commons licence, and indicate if changes were made. The images or other third party material in this article are included in the article's Creative Commons licence, unless indicated otherwise in a credit line to the material. If material is not included in the article's Creative Commons licence and your intended use is not permitted by statutory regulation or exceeds the permitted use, you will need to obtain permission directly from the copyright holder. To view a copy of this licence, visit http://creativecommons.org/licen ses/by/4.0/.

\section{References}

Agence France Presse (1991) Chinese banks lost money with BCCI: report. Agence France Presse, Hong Kong, 2 August 1991

Ahl B (2019) Judicialization in authoritarian regimes: the expansion of powers of the Chinese Supreme People's Court. Int J Const Law 17:252-277

Arsenault SJ (2011) Leaping over the Great Wall: examining cross-border insolvency in China under the Chinese corporate bankruptcy law. Ind Int \& Comp Law Rev 21:1-24

Barboza D (2009) Danone exits China venture after years of legal dispute. New York Times, 30 September 2009

Blackwell H (2017) Recent developments in the PRC: a change in tide for arbitration? Kluwer Arbitration Blog. http://arbitrationblog.kluwerarbitration.com/2017/12/05/recent-developments-prcchange-tide-arbitration/. Accessed 4 May 2020

Blom-Cooper LJ (1954) Bankruptcy in English private international law - I: survey of foreign systems. Int \& Comp Law Q 3:604-623

Booth CD, Lewis DJ (1990) Liwan District Construction Company v. Euro-American China Property Limited, case digest. China Law \& Practice 4:27-34

Brand RA (2018) Recognition of foreign judgments in China: the Liu case and the Belt and Road Initiative. J Law \& Com 37:29-56 
Brattberg E, Corre PL (2020) The EU and China in 2020: more competition ahead. Carnegie Endowment for International Peace. https://carnegieendowment.org/files/1-31-20_Brattberg_Le_Corre_ EU_China.pdf. Accessed 11 June 2020

Brodsgaard KE (2012) Politics and business group formation in China: the party in control? China Q 211:624-648

Bu Q (2009) China's Enterprise Bankruptcy Law (EBL 2006): cross-border perspectives. Int Insolv Rev 18:187-208

Chen L, Jiang X (2018) Chenren he zhixing waiguo fayuan panjue zhong huhui yuance de xianchuang yingxiang yu gaijing (承认和执行外国法院判决中互惠原则的现状、影响与改进) [Reciprocity in foreign judgment recognition: present, effect and reform]. Falu shiyun (法律适用) [Journal of Law Application] 5:16-23

Chen J, Xiao B (2018) Yidai yilu beijingxia chenren yu zhixing waiguo panjue zhong huhui yuanze shiyun de biange ji jianyi (一带一路背景下承认与执行外国判决中互惠原则适用的变革及建 议) [Application of reciprocity in recognition and enforcement of foreign judgments in the context of the Belt \& Road Initiative: latest development and reform recommendations]. Jiangsu shehui kexue (江苏社会科学) [Jiangsu Social Sciences] 2:254-263

Cheng R (2018) Ziyou maoyi gang jianshe beijing xia de huhui zhi gaige (自由贸易港建设背景下的 互惠制改革) [Reforming the Principle of Reciprocity in the Context of Establishing Free Trading Ports in China]. Faxue (法学) [Legal Science] 11:75-85

Chua EJ (2006) Bankruptcy reform in China. Pratt's J Bankr Law 1:552-561

Clarke D (2017) Chinese court enforces Singapore judgment on the basis of reciprocity. Chinese Law Prof Blog. https://lawprofessors.typepad.com/china_law_prof_blog/2017/02/chinese-court-enfor ces-singapore-judgment-on-the-basis-of-reciprocity.html. Accessed 29 May 2020

Haitong Securities Co., Ltd. (2018) Zhongguo hongguan shuifu, gao zai nali, cong nali jiang (中国 宏观税负: 高在哪里, 从哪里降?) [China's National Tax Fairness: Where to Seek the Balance]. https://www.htsec.com/jfimg/colimg/upload/20180726/44891532588358341.pdf. Accessed 29 May 2010

Daoming Optics \& Chemical Co., Ltd. (2014) Jianshi quanyi biandong baogao shu (简式权㿽变动报 告书) [The simplified equity alteration report]. Yongkang Zhejiang China, 11 December 2014

Daoming Optics \& Chemical Co., Ltd. (2017) Zaichuang jingying jiaji, luxing shehui zhize, daoming guangxue zaici chanlian Yongkang shi nashui dahu (再创经营佳绩、履行社会责任 一 道 明光学再次蝉联永康市纳税大户) [Strengthen operational efficiency and fulfil social obligations: Daoming is continuously qualified as a substantial taxpaying company in Yongkang]. http://www.chinadaoming.com/uploads/20200326/7bc1769d94737196a945749b958f609f.pdf. Accessed 26 May 2020

Daoming Optics \& Chemical Co., Ltd. (2019a) 2018 nian niandu baogao (2018年年度报告) [The 2018 annual report]. Yongkang Zhejiang China, April 2019. http://static.cninfo.com.cn/final page/2019-04-30/1206160025.PDF. Accessed 26 May 2020

Daoming Optics \& Chemical Co., Ltd. (2019b) 2019 nian ban niandu baogao (2019年牛年度报告) [The 2019 first half-year report]. http://static.cninfo.com.cn/finalpage/2019-08-23/1206555291.PDF. Accessed 26 May 2020

Coco SE (2019) The value of a new judgments conventions for U.S. litigants. NYUL Rev 94:1209-1243

Cohen JA (2014) Settling international business disputes with China: then and now. Cornell Int Law J 47:555-568

Colombo G et al (2020) Cross-border insolvency in Brazil: a case for the Model Law. https://www.uncit ral.org/pdf/english/congress/Papers_for_Congress/117-COLOMBO_KAYE_LANGEN_LUTKUS_ SHIRLEY_and_TURETSKY-_Cross-Border_Insolvency_in_Brazil.pdf. Accessed 4 May 2020

Coyle JF (2014) Rethinking Judgments Reciprocity. NCL Rev 92:1109-1174

Deane F, Mason R (2016) The UNCITRAL Model Law on Cross-Border Insolvency and the rule of law. Int Insolv Rev 25:138-159

Duan F (2011) Recognition and enforcement of foreign bankruptcy judgments and orders in China. Insolv \& Restructuring Int 5:18-21

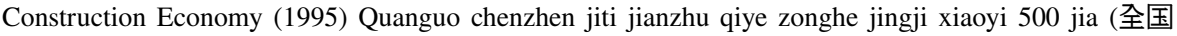
城镇集体建筑企业综合经济效盆500家) [China national top 500 profitable township collectivelyowned construction enterprises]. Jianzhu jingji (建筑经济) [Construction Economy] 1:33-34

Fletcher I (2014) Spreading the gospel: the mission of insolvency law, and insolvency practitioners, in the early 21 st century. JBL 7:523-540 
Friedmann W (1963) The uses of general principles in the development of international law. Am J Int Law 57:279-299

Godwin A et al (2017) The inherent power of common law courts to provide assistance in cross-border insolvencies: from comity to complexity. Int Insolv Rev 26:5-39

Gong X (2011) When Hong Kong becomes SAR, is the mainland ready: problems of judgments recognition in cross-border insolvency matters. Int Insolv Rev 20:57-74

Gong S (2018) The Chinese court's enforcement of a US civil judgement. Transnational notes, the Centre for Transnational Litigation, Arbitration, and Commercial Law, New York University. https:// blogs.law.nyu.edu/transnational/2018/04/the-chinese-courts-enforcement-of-a-u-s-civil-judgement/. Accessed 22 May 2020

Halliday TC, Osinsky P (2006) Globalization of Law. Ann Rev Soc 32:447-470

He Q (2018) Chronology of practice: Chinese practice in private international law in 2017. Chinese J Int Law 17:1101-1146

He S (2014) Zhejiang Haining fayuan kuajing panhuo haiwai zichan (浙江海宁法院跨境盘活海外资产) [Zhejiang Haining Court helps to collect assets overseas by using cross-border insolvency rules]. Renmin fayuan bao (人民法院报) [People's Court Daily]. Beijing China, 17 November 2014

Hu K (2017) Ganyan shanyan, Zong Qinghuo daibiao luzhi shiwunian zuole naxieshi (敢言善言, 宗庆后 代表履职十五年做了哪些事?) [Diligence and integrity: what has been done by Mr Zong Qinghuo as a member of the China National People's Congress in the past fifteen years?]. Xinhua wang (新 华网) [Xinhua Net]. Beijing China, 3 March 2017. http://www.xinhuanet.com//food/2017-03/03/c_ 1120561600.htm. Accessed 27 May 2020

Huang J (2019) Reciprocal recognition and enforcement of foreign judgments in China, the proposal for a registration system. In: Michael D et al (eds) Commercial issues in private international law: a common law perspective. Hart Publishing, Oxford, chapter 6

International Monetary Fund (2019) IMF country report No 19/266, People's Republic of China. https:// www.imf.org/en/Publications/CR/Issues/2019/08/08/Peoples-Republic-of-China-2019-Article-IVConsultation-Press-Release-Staff-Report-Staff-48576. Accessed 22 April 2020

Jiang X (2017) Nanning declaration approved at the Justice Forum. http://english.court.gov.cn/2017-06/ 09/content_29686326.htm. Accessed 23 May 2020

Kargman ST (2012) Emerging economies and cross-border insolvency regimes: missing BRICs in the international insolvency architecture (part I). Insolv and Restructuring Int 6:8-15

Ke Z (2014) Yijia zhuanrang, hua'an jijing guquan biandong jiemu (溢价转让, 华安基金股权变动揭幕) [Sold at a premium: revelation of the equity changes of Hua'an Fund Limited]. Shidai zhoubao (时 代周报) [The Time Weekly]. Guangzhou Guangdong China, 6 March 2014. http://www.p5w.net/ fund/gsdt/201403/t20140306_507072.htm. Accessed 24 May 2020

Kirshner J (2013) The (false) conflict between due process rights and universalism in cross-border insolvency. CLJ 72:27-31

Kotuby CT Jr (2013) General principles of law, international due processes and the modern role of private international law. Duke J Comp \& Int Law 23:411-444

Lee E (2014) Comparing Hong Kong and Chinese insolvency laws and their cross-border complexities. J Comp Law 9:259-280

Lee J, Jin H (2016) More Hanjin ships seized, as freight rates surge and cargo owners fret. Reuters, London, 1 September 2016. https://uk.reuters.com/article/uk-hanjin-shipping-debt-ports/more-hanjinships-seized-as-freight-rates-surge-and-cargo-owners-fret-idUKKCN1174HK. Accessed 14 May 2020

Levin D (2016) Canada agrees to talks on extradition treaty with China. New York Times, 20 September 2016. https://www.nytimes.com/2016/09/21/world/americas/canada-agrees-to-talks-with-china-onextradition.html. Accessed 16 May 2020

Li X (2019) Reforming Chinese cross-border bankruptcy law during a trade war: has the Supreme People's Court provided a satisfying answer? Hong Kong Law J 49:1057-1088

Li X, Tu G (2018) Recent development in recognition of and assistance to foreign insolvency representatives under the Hong Kong common law. Int Insolv Rev 27:32-57

Li S, Huang D (2017) Shanghai haishi fayuan yishen shenjie quanbu she hanjin gongsi zhaiwu weiji anjian (上海海事法院一审审结全部涉韩进公司债务危机案件) [The Shanghai Maritime Court has completed all Hanjin-related lawsuits]. Zhongguo xingwen wang (中国新闻网) [China News Service]. Beijing China, 23 January 2017. http://www.chinanews.com/sh/2017/01-23/8133592. shtml. Accessed 24 May 2020 
Li S, Zhao Q (2018) Lun chenren he zhixing waiguo fayuan panjue shenqing zhi sifa shencha (论承认和 执行外国法院判决申请之司法审查) [Judicial assessment of foreign judgment recognition applications]. Falu shiyun (法律适用) [J Law Appl] 5:24-30

Liu R (2018) Woguo pizhun xuanze fayuan xieyi gongyue de wenti yu duice (我国批准选择法院协议 公约的问题与对策) [China's ratification of the Hague Convention on choice of court agreements: challenges and solutions]. Faxue yanjiu (法学硏究) [Chinese Journal of Law] 4:188-208

LoPucki LM (1999) Cooperation in international bankruptcy: a post-universalist approach. Cornell Law Rev 84:696-762

Luo S (2017) Goujian gongzhen gaoxiao bianli de yidai yilu kuajing jiufeng jiejue jizhi (构建公正高效 便利的一带一路跨境纠纷解决机制) [Establish a just, efficient and convenient dispute resolution system in support of the Belt \& Road Initiative]. Renmin fayuanbao (人民法院报) [The People's Court Daily]. Beijing China, 27 September 2017

McCormack G (2012) Universalism in insolvency proceedings and the common law. Oxford J Legal Stud $32: 325-348$

McCormack G (2016) Something old, something new: recasting the European Insolvency Regulation. MLR 79:121-146

McCormack G, Wan WY (2019) The UNCITRAL model law on cross-border insolvency comes of age: new times or new paradigms. Tex Int Law J 54:273-304

Moss G (2019) UNCITRAL Model Law on recognition and enforcement of insolvency-related judgments. Insolv Int 32:21-24

Parry R, Gao N (2018) The future direction of China's cross-border insolvency laws, related issues and potential problems. Int Insolv Rev 27:5-31

Paulus CG (2019) The German Supreme Court's understanding of the universality principle. Insolv Int $32: 27-29$

Roberts CW (2017) Hanjin's legacy - two cents on the dollar: a case for reforming Chapter 15 of the bankruptcy code and enforcement of maritime liens. USF Mar Law J 30:1-18

Shambaugh D (2007) China's propaganda system: institutions, progresses and efficacy. China J 57:25-58

Shanghai International Port (Group) Co., Ltd. (2018) 2017 nian niandu baogao (2017年年度报告) [The 2017 annual report]. http://file.finance.sina.com.cn/211.154.219.97:9494/MRGG/CNSESH_ STOCK/2017/2017-3/2017-03-29/3157081.PDF. Accessed 24 May 2020

Shi J (2001) Chinese cross-border insolvencies: current issues and future developments. Int Insolv Rev $10: 33-58$

Shi J, Huang Y (2017) Kuajing pochan zhong de chenren yu jiuji zhidu (跨界破产中的承认与救济制 度) [The Recognition and Relief in Cross-Border Insolvency]. Zhongguo renmin daxue xuebao (中 国人民大学学报) [J Renmin Univ China] 2:34-45

Shi J (2002a) Recent developments in Chinese cross-border insolvencies. https://www.iiiglobal.org/sites/ default/files/2-_060710shi-3.pdf. Accessed 6 May 2020

Shi J (2002b) Zhongguo de kuajie pochan fa: xianzhuang, wenti ji fazhan(中国的跨界破产法: 现状、 问题及发展) [China's cross-border insolvency law: present, problems and future]. Zhongguo Faxue (中国法学) [China Legal Science] 1:114-123

Simowitz AD (2019) Convergence and the circulation of money judgments. S Cal Law Rev 92:1031-1054

Song J (2019) Cross-border insolvency: a review from Chinese courts. INSOL World 1:25-26

Song S (2016) Government mulls additional measures to minimise Hanjin's impact on exports. The Korea Herald. Seoul South Korea, 4 September 2016. http://www.theinvestor.co.kr/view.php?ud= 20160904000261. Accessed 24 May 2020

Trautman DT et al (1993) Four models for international bankruptcy. Am J Comp Law 41:573-626

Tsang KF (2017) Chinese bilateral judgment enforcement treaties. Loy LA Int \& Comp Law Rev 40:1-50

Walters A (2019) Modified universalisms \& the role of local legal culture in the making of cross-border insolvency law. Am Bankr Law J 93:47-100

Walters A (2020) The UNCITRAL Model Law on recognition and enforcement of insolvency-related judgments. Comp Law 41:91-92

Wang M, Lian C (2008) Yuwai panjue de chenren yu zhixing - yi dui faguo yiqi pochan panjue de chenren weili (域外判决的承认与执行一以对法国一起破产判决的承认为例) [Recognition of Foreign Judgment - a Case of Recognising a French Bankruptcy Judgment in China]. http://www. gzhsfy.gov.cn/web/content/18260-?lmdm=1016. Accessed 6 June 2019

Wang Y (2019) Waiguo fayuan panjue chenren yu zhixing zhong huhui de rending biaozhun (外国法 院判决承认与执行中互惠的认定标准) [Criteria of acknowledging reciprocity in recognising and 
enforcing foreign judgments]. Wuda guojifa pinlun (武大国际法评论) [Wuhan University International Law Review] 4:20-38

Wessels B (2008) International insolvency law in the Netherlands: the pre-draft of title 10. Int Insolv Rev 17:143-162

Westbrook JL (2015) Interpretation internationale. Temp Law Rev 87:739-758

Westbrook JL (2018) Global insolvency proceedings for a global market: the universalist system and the choice of a central court. Tex Law Rev 96:1473-1494

Xiao C (2017) Deng Qingmao, Jiangxishen lidu yanhua jituan chuangshiren jieshao (邓庆茂 一 江西 省李渡烟花集团创始人介绍) [Mr Deng Qingmao, the founder of Jiangxi Province Lidu Group]. http://www.lidufireworks.cn/renwufengcai/2017-12/21/NewsView-164.html. Accessed 26 May 2020

Xie X (2010) Tiaoyue yu huhui queshi shi zhongguo panjue de yuwai shixing (条约与互惠缺失时中国 判决的域外执行) [Chinese judgments recognised and enforced abroad in the absence of treaty and reciprocity]. Huanxiu falu pinlun (环球法律评论) [Global Law Review] 4:152-159

Xinfu Law Firm (2001) Daili chenren waiguo fayuan caijue an, woshi lushi yewu de zhongda kaituo (代理承认外国法院裁玦案, 我市律师业务的重大开拓) [A new frontier of the legal services in Foshan and our lawyers helped foreign clients to have Italian bankruptcy judgment recognised in China]. http://www.xinfulaw.com/cn/anli/al001.html. Accessed 13 June 2019

Xu L (2018) Being open-minded in interpreting the reciprocity principle when dealing with foreign judgment recognition in China. Stanford Law School, China Guiding Cases Project. https://cgc.law.stanf ord.edu/zh-hans/commentaries/clc-1-201806-insights-3-alison-xu/. Accessed 4 June 2020

Zhang W (2013) Recognition and enforcement of foreign judgments in China: a call for special attention to both the 'due service requirement' and the 'principle of reciprocity.' Chin J Int Law 12:143-174

Zhang W (2017) Sino-foreign recognition and enforcement of judgments: a promising 'follow-suit' model. Chinese J Int Law 16:515-546

Zhang X, Booth CD (2002) Beijing's initiative on cross-border insolvency: reflections on a recent visit of Hong Kong professionals to Beijing. Am Bankr Inst Law Rev 10:29-40

Zhang Y, Yang L (2019) Sifa jiguan xianghu chenren zhixing minshangshi panjue de xing tansuo (司 法机关相互承认执行民商事判决的新探索) [The novel experiment of mutually recognising and enforcing foreign judgments]. Renmin sifa (人民司法) [The people's judicature] 13:20-24

Zhang F (2011) Huaan jijing yu leiman ouzhou jingrong yianshen chanpin tuozi hezuo jiufeng an (华 安基金与雷曼欧洲金融衍生产品投资合作纠纷案) [China's financial law reforms, lessons of Hua' an Fund Limited and Lehman Brothers Europe Limited]. In: Ying Y (ed) Jingrong fazhi qianyan (金融法制前沿) [The frontier of financial law]. Falu chubanshe (法律出版社) [Law Press], Beijing, pp 58-77

Zhao T (2014) Jining shenjie Shandong shouli waiguo fayuan shenqing chenren shangshi panjue an (济宁 审结山东首例外国法院申请承认商事判决案) [The Jining Intermediate People's Court successfully dealt with the first foreign judgment recognition case]. Zhonguo fayuan wang (中国法院网) [The China Court Net]. Beijing China, 25 February 2014. https://www.chinacourt.org/article/detail/ 2014/02/id/1219259.shtml. Accessed 28 May 2020

Zhao X (2017) Cong yiqi haishi haishang jiufeng tan bufangbian fayuan yuanze (从一起海事海商纠纷 谈不方便法院原则) [The Inconvenient Court Principle: the Study of a Maritime Dispute]. Zhongguo lushi (中国律师) [Chinese Lawyer] 9:102-104

Zheng W (2012) Zhongguo yingdui kuaguo pochan falu wenti de celue xuanze (中国应对跨国破产法律 问题的策略选择) [Strategic solutions for cross-border insolvency in China]. Dangdai faxue (当代 法学) [Contemporary Law Review] 1:126-132

Zhou P (2016) Hanjin Shipping's hurdles for Chinese bankruptcy recognition highlight country's crossjurisdictional challenges. https://www.debtwire.com/info/hanjin-shipping's-hurdles-chinese-bankr uptcy-recognition-highlight-country's-cross-jurisdictional. Accessed 14 May 2020

Zhu L (2018) The Kolmar v. Sutex case on reciprocity in foreign judgments enforcement in China: a welcome development or still on the wrong track? Frontiers Law China 13:202-217

Publisher's Note Springer Nature remains neutral with regard to jurisdictional claims in published maps and institutional affiliations. 